\title{
Non-infective occupational risk factors for hepatocellular carcinoma: A review (Review)
}

\author{
CATERINA LEDDA ${ }^{1,2^{*}}$, CARLA LORETO $^{3 *}$, CHRISTIAN ZAMMIT $^{4}$, ANDREA MARCONI $^{1}$, LUCREZIA FAGO $^{1}$, \\ SERENA MATERA $^{1}$, VALENTINA COSTANZO ${ }^{1}$, GIOVANNI FUCCIO SANZ $\AA^{5}{ }^{2}$, STEFANO PALMUCCI ${ }^{5}$, \\ MARGHERITA FERRANTE ${ }^{2}$, CHIARA COSTA ${ }^{6}$, CONCETTINA FENGA $^{6}$, ANTONIO BIONDI ${ }^{7}$, \\ CRISTOFORO POMARA ${ }^{4,8}$ and VENERANDO RAPISARDA ${ }^{1}$
}

\author{
${ }^{1}$ Occupational Medicine, Department of Clinical and Experimental Medicine; ${ }^{2}$ Hygiene and Public Health, \\ Department of Medical Sciences, Surgical and Advanced Technologies 'GF Ingrassia'; ${ }^{3}$ Human Anatomy and Histology, \\ Department of Biomedical and Biotechnology Sciences, University of Catania, I-95123 Catania, Italy; ${ }^{4}$ Anatomy Department, \\ Faculty of Medicine and Surgery, University of Malta, MSD-2080 Msida, Malta; ${ }^{5}$ Division of Radiology, \\ 'Policlinico-Vittorio Emanuele' University Hospital, University of Catania, I-95123 Catania; ${ }^{6}$ Occupational Medicine, \\ Department of the Environment, Safety, Territory, Food and Health Sciences, University of Messina, I-98125 Messina; \\ ${ }^{7}$ General Surgery, Department of General Surgery and Medical-Surgical Specialties, University of Catania, I-95123 Catania; \\ ${ }^{8}$ Forensic Pathology, Department of Clinical and Experimental Medicine, \\ University of Foggia, I-71122 Foggia, Italy
}

Received March 24, 2015; Accepted July 1, 2016

DOI: $10.3892 / \mathrm{mmr} .2016 .6046$

\begin{abstract}
Liver cancer is the second leading worldwide cause of cancer-associated mortalities. Hepatocellular carcinoma, which accounts for the majority of liver tumors, ranks fifth among types of human cancer. Well-established risk factors for liver cancer include the hepatitis B and C viruses, aflatoxins, alcohol consumption, and oral contraceptives. Tobacco smoking, androgenic steroids, and diabetes mellitus are suspected risk factors. Current knowledge regarding non-infective occupational risk factors for liver cancer is inconclusive. The relevance of liver disorders to occupational medicine lies in the fact that the majority of chemicals are metabolized in the liver, and toxic metabolites generated via metabolism are the predominant cause of liver damage. However, their non-specific clinical manifestations that are similar in a number of liver diseases make diagnosis difficult. Furthermore, concomitant conditions, such as viral hepatitis and alcohol or drug abuse, may mask liver disorders that result from occupational hepatotoxic agents and block the demonstration of an occupational cause. The identification
\end{abstract}

Correspondence to: Professor Venerando Rapisarda, Occupational Medicine, Department of Clinical and Experimental Medicine, University of Catania, 78 Via Santa Sofia, I-95123 Catania, Italy

E-mail: vrapisarda@unict.it

*Contributed equally

Key words: hepatocellular carcinoma, occupational exposure, POPs, chemical agent, xenobiotic, pollutant of environmental agents that result in human cancer is a long and often difficult process. The purpose of the present review is to summarize current knowledge regarding the association of non-infective occupational risk exposure and HCC, to encourage further research and draw attention to this global occupational public health problem.

\section{Contents}

1. Introduction

2. Methods

3. Results

4. Risk prevention in the workplace

5. Conclusion

\section{Introduction}

Liver cancer is the second leading cause of cancer-associated mortality worldwide; in 2012 it was responsible for $\sim 746,000$ mortalities (1). Hepatocellular carcinoma (HCC), which accounts for the majority of liver tumors, ranks fifth among human cancers, with $\sim 750,000$ new cases arising worldwide each year (2).

The widely variable geographic distribution and occurrence of liver cancer in immigrant populations demonstrate that the predominant factors involved are environmental (3). Liver cancer is most common in less developed countries, as demonstrated by the fact that in 2012 as many as $83 \%$ of the estimated 782,000 new cases worldwide occurred in such areas.

Well-established risk factors for liver cancer include hepatitis B virus (HBV), hepatitis C virus (HCV) (4-7), 
aflatoxins (4-7), alcohol consumption $(5,6)$, and oral contraceptives (8). Tobacco smoking, androgenic steroids, and diabetes mellitus are suspected risk factors $(5,6)$.

Current knowledge regarding non-infective occupational risk factors and liver cancer is inconclusive, except for the well-established association between vinyl chloride monomer (VCM) and angiosarcoma of the liver (ASL) (9).

High liver cancer mortality has been reported among heavy construction equipment operators (10), chimney sweepers (11), chemical workers (12), seamen (13) and painters (14). A meta-analysis by Chen and Seaton (15) found a standardized mortality ratio (SMR) of 1.20 [95\% confidence interval (CI), 1.04-1.37] for solvent exposure (15). A previous study of biliary duct and liver cancer investigating occupational exposure to methylene chloride in a factory producing cellulose fibers observed an SMR of 0.81 (95\% CI, 0.02-4.49) for high exposure and an SMR of 0.75 (95\% CI, 0.02-4.20) for low exposure (men only) (16). A census-linkage study conducted in Shanghai, China, found modest excesses among men operating textile machinery [standardized incidence ratio (SIR), 1.64; $\mathrm{P}<0.01]$, bleachers, dyers, and textile workers ( $\mathrm{SIR}=1.52$; $\mathrm{P}<0.01)(17)$. Data from multiple population-based case-control studies suggest an association between occupational exposure and primary liver cancer. In a case-control study from Texas, USA, male textile workers, whose job was not specified, were demonstrated to be at higher risk of liver cancer mortality (18). An international multicenter case-control study indicated an increased HCC risk among female chemical industry workers (19). However, these studies have often failed to identify a single agent responsible for the increased HCC risk.

Investigations into the role of occupational exposure in inducing liver cancer are rare. A number of factors, predominantly including small sample size, inconsistent case definition, and incomplete adjustment for confounders, have precluded drawing firm conclusions. Furthermore, occupation classification has often relied on crude, surrogate, exposure-associated measures based on the industry's characteristics, job or task, and exposure duration (20). The purpose of this review is to summarize current knowledge regarding the association of non-infective occupational risk exposure and $\mathrm{HCC}$, to promote further research and draw attention to this global occupational and public health problem.

\section{Methods}

Research publications on the incidence and mechanisms of HCC development due to occupational exposure to non-infective risk factors of the past 45 years were searched for in three databases: Medline (www.ncbi.nlm.nih.gov/pubmed), Scopus (www.scopus.com/) and Cumulative Index to Nursing and Allied Health Literature (www.ebscohost.com/nursing/products/cinahl-databases/the-cinahl-database).

The MeSH term Unique ID D006528 was used to identify the pathology with the following entry terms: Carcinomas, hepatocellular; hepatocellular carcinomas; liver cell carcinoma, adult; liver cancer, adult; adult liver cancer; adult liver cancers; cancer, adult liver; cancers, adult liver; liver cancers, adult; liver cell carcinoma; carcinoma, liver cell; carcinomas, liver cell; cell carcinoma, liver; cell carcinomas, liver; liver cell carcinomas; hepatocellular carcinoma; hepatoma; and hepatomas; together with occupational, work and occupational disease. Only published data for humans was considered and studies with imprecise descriptions of exposure or diagnosis were rejected. Toxicological studies, particularly studies of biochemical pathways, were not included.

Languages other than English were not an exclusion criterion. HCC cases not directly linked to occupational or environmental exposure were excluded.

\section{Results}

A wide range of occupational activities may involve worker exposure to a variety of chemical agents. The liver is the predominant organ involved in metabolism in the toxicokinetics of a xenobiotic (21). However, it is frequently also a target organ, due to the characteristics of its blood supply and its role in numerous metabolic and excretory processes. Adverse effects of chemical exposure involving the liver (hepatotoxicity) comprise hepatocellular damage, cholestatic injury, fatty liver, granulomatous disease, cirrhosis, and malignancies, including HCC. A variety of chemicals, including VCM, organic solvents, chlorinated pesticides, and arsenic exert adverse effects on the liver (22), some of these are presented in Tables I and II.

\section{Inorganic risk factors}

Arsenic (As). As [Chemical Abstracts Service (CAS) no. 7440-38-2] is a naturally occurring element that is widespread in the Earth's crust. In the environment, it combines with oxygen, chlorine, and sulfur to form inorganic As compounds. The primary route of exposure is groundwater contamination with inorganic As (96).

Inorganic As compounds are predominantly used to preserve wood, for example, copper chromated arsenic (CCA) is used to make pressure-treated lumber. Organic As compounds are employed as pesticides, primarily to treat cotton plants (97). The most heavily exposed workers are currently those from industries using As-containing compounds, including carpentry involving CCA pressure-treated lumber and copper or lead smelting (97). As is also used in the pharmaceutical industry, to treat certain types of neoplasms (98), in the glass industry, in the manufacture of alloys, sheep dips, leather preservatives, a number of pigments, antifouling paints and poison baits and, increasingly rarely, in the production of agrochemicals, particularly for use in orchards and vineyards. As compounds are employed in limited quantities in the microelectronics and optical industries (99-102). High air As levels can be found in the working environment, as well as in the general environment around non-ferrous metal smelters, where As trioxide may be formed, and in the vicinity of certain coal-fired power plants, particularly those using low-grade brown coal $(96,97)$.

As is absorbed from the gastrointestinal tract and first reaches the liver, where arsenate is reduced to arsenite $(103,104)$. The liver is rich in glutathione, thus, it is a major site for As detoxification, either with glutathione acting as an antioxidant or by glutathione-arsenic conjugation for cellular efflux and biliary excretion $(104,105)$. The liver is also the major site of As methylation, which is catalyzed by arsenic methyltransferase with S-adenosylmethionine as the substrate (106). 
Table I. Metal agents, occupational exposure and IARC classification.

IARC

First author, year

CAS no. Agent

classification Occupational exposure

Refs.

IARC, 2011; McElvenny, 2014; 7440-38-2 Arsenic

Bolognesi, , 2014; de Vocht, 2007;

Jönsson, 2009; Iavicoli, 2006
Group 1

Coal-fired power plants; As extraction industry; timber manufacturing; glass industry; pesticides use; lead processing; pharmaceutical industry; leather preservatives; antifouling paints; agrochemicals production; microelectronics and optical industries; non-ferrous metal smelters

Baccarelli, 2002; NIOSH, 2015; 7440-43-9 Cadmium Group 1 Ni-Cd battery manufacturing, Cd Tijet, 2006; Walker, 2005 alloy production; $\mathrm{Cd}$ mining; manufacturing of Cd-containing ores and products
$(23-28)$

IARC, International Agency for Research on Cancer; CAS, Chemical Abstracts Service; NIOSH, National Institute of Occupational Safety and Health.
As is an International Agency for Research on Cancer (IARC) Group 1 carcinogen. Chronic exposure to As is associated with cancer of the skin, lungs, bladder, liver, kidneys, and prostate in humans (107-109). Epidemiological findings, supported by data from case reports and from rodent and cell model systems, indicate that the liver is a target of As carcinogenesis. Epidemiology studies have also demonstrated an association between chronic As exposure and pre-neoplastic lesions, abnormal liver function, hepatomegaly, hepatoportal sclerosis, liver fibrosis, cirrhosis, and ASL $(104,110)$.

It is important to differentiate between exposure to inorganic and organic As, as only inorganic compounds have been associated with cancer (111). Monomethylarsonic acid and dimethylarsinic acid are the active ingredients of certain herbicides and are inorganic As metabolites. On the basis of sufficient evidence of cancer in experimental animals, and as monomethylarsonic acid is extensively metabolized to dimethylarsinic acid, the two compounds are classified as possibly carcinogenic to humans (IARC Group 2B). Organic As is predominantly found in food (for example, seafood), while inorganic As is predominantly present in drinking water $(96,97)$. In the latest IARC monograph, As was considered limited in the induction of liver cancer in experimental animals (108). However, more recent laboratory data from rodents and cell model systems have indicated that the liver is a major target for carcinogenesis from inorganic As (104,111-115).

The exact mode of action (MOA) of As carcinogenicity, including hepatocarcinogenesis, require further elucidation. Various potential mechanisms have been suggested including epigenetic and genetic mechanisms, including oxidative DNA damage (105), alteration of apoptosis (116), increased cell proliferation (117), irregular DNA methylation (118), genome instability (119), and abnormal estrogen signaling (120).

In occupationally exposed subjects, urinary As may be used to assess the level of occupational exposure (101).

Cadmium (Cd). Cd (CAS no. 7440-43-9) is a silver-white, metal or grayish-white powder. It occurs in the environment as isotopes, 8 of which are stable and 2 radioactive. $\mathrm{Cd}$ was identified in Germany in 1817 and used as a pigment due to its ability to produce brilliant yellow, orange, and red colors. It subsequently became an important material in the manufacturing of rechargeable nickel-Cd (Ni-Cd) batteries and as a corrosion-protection coating for iron and steel.

Workplace exposure to $\mathrm{Cd}$ and $\mathrm{Cd}$ compounds predominantly involves exposure to airborne dusts and fumes. It occurs chiefly during mining and work with $\mathrm{Cd}$-containing ores, during manufacture and formulation of Cd-containing products, such as paints and pigments, and during activities, including soldering, welding, painting, metal machining, mechanical plating, and zinc smelting (120). Cd pigment manufacture and formulation, $\mathrm{Cd}$ alloy production, $\mathrm{Cd}$ production and refining, Ni-Cd battery manufacture, mechanical plating, soldering, zinc smelting and polyvinyl chloride (PVC) compounding are associated with the highest potential exposures (121). Current industrial uses of $\mathrm{Cd}$ are in batteries, alloys, coatings (electroplating), solar cells, plastic stabilizers, and pigments. Cd is also used in nuclear reactors as a neutron absorber. Workers involved in landfill operations, and the recycling of electronic parts or of plastics may be exposed to Cd. Compost workers and waste collectors are also potentially exposed to dust that may contain $\mathrm{Cd}$ and the incineration of municipal waste is a further source of $\mathrm{Cd}$ exposure $(120,122)$. Increased investment in solar power is expected to increase $\mathrm{Cd}$ use in the future.

$\mathrm{Cd}$ found in food and cigarette smoke accumulates in the liver, kidney, and pancreas. Liver concentrations increase with age, peaking at 40-60 years $(123,124)$. Long-term inhalation or oral exposure typically leads to build-up in the kidneys and the liver, where it has the potential to induce disease (120-125). In workplaces, chronic inhalation and oral exposure results in lung damage, including bronchiolitis and emphysema $(120,122,125)$. In animals, long-term inhalation or oral exposure exerts adverse effects on the kidneys, lungs, bones, liver, immune system, nervous systems and blood (126). 


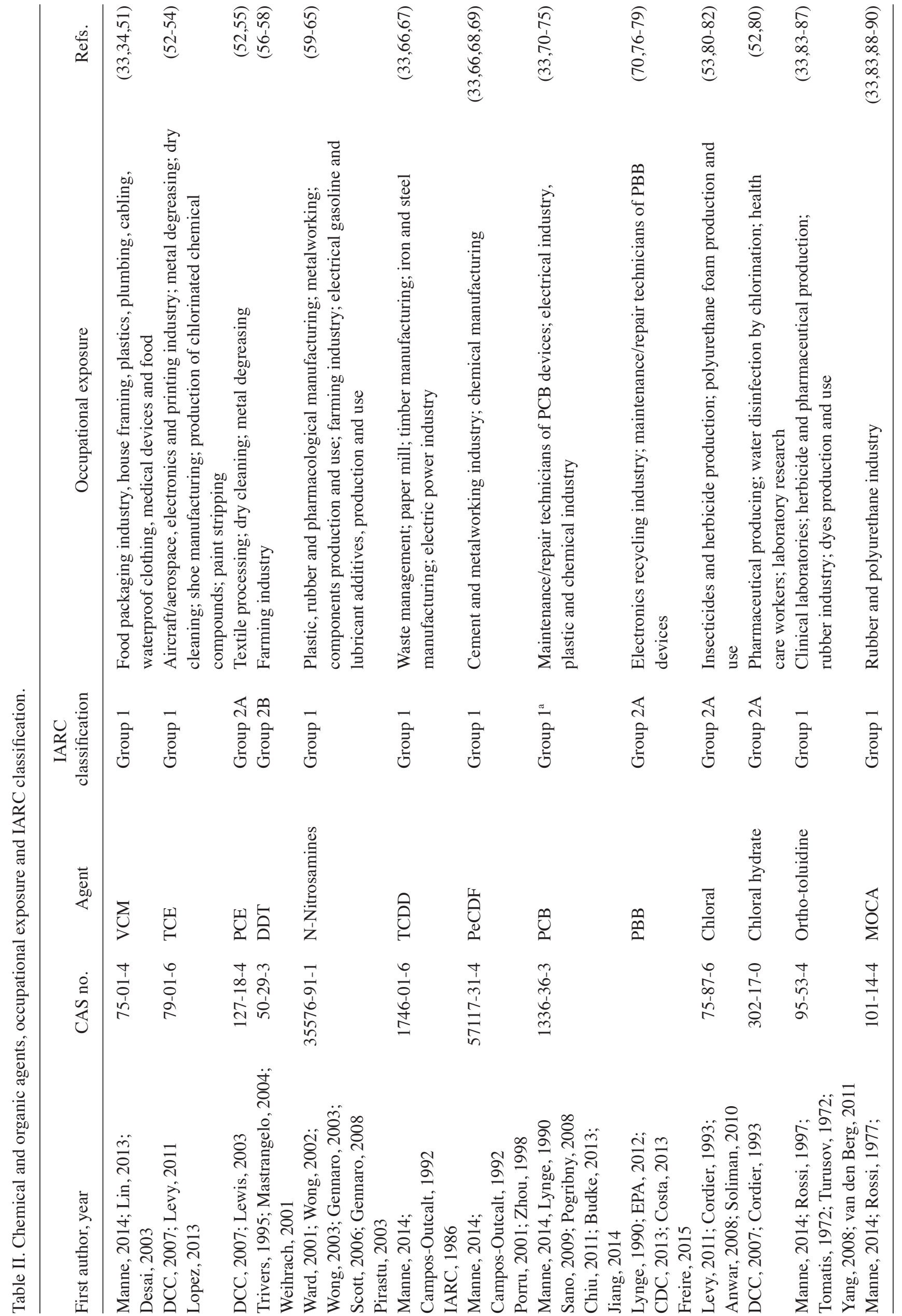


Review and evaluation of epidemiological findings and other relevant information on $\mathrm{Cd}$ exposures resulted in the IARC conclusion that $\mathrm{Cd}$ is carcinogenic to humans (125).

The hepatocarcinogenic potential of $\mathrm{Cd}$ has attracted little attention, despite an association between dietary intake, predominantly of plant origin, and HCC mortality being observed two decades ago in a large and comprehensive cross-sectional study conducted in China (127).

A standard two-year bioassay was used to evaluate the carcinogenic potential of $\mathrm{Cd}$ in two mouse strains, DBA/2NCr (DBA) and NFS/NCr (128). Cd resulted in liver cancer, sarcoma, lung cancer and testicular cancer in male NFS mice, and lymphoma in male DBA mice; carcinogenicity was demonstrated to vary with dose, animal strain, and route of exposure (124). HCC development was markedly enhanced in male Wistar rats treated with the hepatocarcinogen dimethylnitrosamine and Cd (129). In another previous study, Cd inoculation (dose level, $1.0 \mu \mathrm{M}$ ) led to 10 -fold increases in the expression of oncogenes c-myc and c-jun, as well as increases in the DNA-binding activity of transcription factors activator protein-1 and nuclear factor- $\kappa \mathrm{B}$ in nude mice. Oncogene overexpression and loss of growth control appeared to be critical in carcinogenicity due to low-level $\mathrm{Cd}$ exposure (124), whereas higher exposure enhanced oxidative stress (130). These data have identified proto-oncogene activation via DNA hypomethylation as a novel epigenetic mechanism underlying the development of cancer cells, induced by prolonged exposure to low-level $\mathrm{Cd}$ (124). The carcinogenic potential of $\mathrm{Cd}$ was studied in vitro using the TRL1215 rat liver epithelial cell line (131). Cd concentrations from $0-2.5 \mu \mathrm{M}$ led TRL1215 cells to undergo malignant transformation following exposure for 10 weeks (131). Cd-exposed TRL1215 cells exhibited phenotypic characteristics of transformed cells, including hyperproliferation, increased invasiveness, and decreased serum dependence. Furthermore, DNA methyltransferase and DNA methylation activity increased, providing, for the first time, suggestive evidence of an epigenetic effect of $\mathrm{Cd}$. Cd has been demonstrated to induce expression of the metal-binding protein metallothionein (MT) in the liver. Liver MT induction results in $\mathrm{Cd}$ sequestration, which underpins its long biological half-life (132). Sabolić et al (133) have reported that MT binds $\mathrm{Cd}$ and enters Kupffer cells. Internalization of protein-bound $\mathrm{Cd}$ by these cells may induce release of various pro-inflammatory cytokines, including interleukin-6 (IL-6). IL-6 produced by Kupffer cells has been implicated in HCC development in a mouse model (134).

In a review of Cd carcinogenicity, Huff et al (121) demonstrated that $\mathrm{Cd}$-induced biochemical changes may be important in all stages of carcinogenicity, including induction of oxidative stress together with decreased DNA repair, aberrant gene expression and signaling combined with inhibition of DNA methylation, which induces proto-oncogenes, and E-cadherin dysfunction breaks cell adhesion.

A multiplicity of effects on the liver due to long-term $\mathrm{Cd}$ exposure, increased cancer mortality in men, and evidence of liver carcinogenicity in mice suggests urgent human case-control studies are required, these should compare individuals with cirrhosis and/or HCC with different $\mathrm{Cd}$ body burden, perhaps as indicated by urinary $\mathrm{Cd}$. Currently, 
biological monitoring of exposed workers involves determination of $\mathrm{Cd}$ level in blood or urine.

\section{Organic risk factors}

VCM and PVC. VCM (CAS no. 75-01-4) is an aliphatic hydrocarbon, also known as chloroethene, whose polymerization produces a synthetic resin known as polyvinyl chloride (PVC). VCM is typically a sweet-smelling, colorless gas that is insoluble in water. It is predominantly used to produce PVC (CAS no. 9002-86-2), which is extensively used in the plastics industry and as a raw material in organic synthesis $(135,136)$. PVC is found in a wide range of products, including water pipes, substitutes for painted wood (window frames, sills, flooring), electrical cable insulation, inflatable products, waterproof clothing (coats, skiing equipment, shoes), medical devices and similar products (tubing, catheters, containers), food packaging, dental appliances, and vinyl records. VCM is also extensively used as a coolant in plastic manufacturing and as an intermediate in organic synthesis. PVC is harmless in its polymeric form, thus, workers handling the finished goods are not at risk of exposure. However, the at-risk phase is manual descaling of the autoclaves used for polymerization, where workers may come into contact with the material in its monomeric state (54).

VCM does not occur naturally and is therefore found almost exclusively in factories making PVC. Small quantities of VCM are found in finished plastic products, the highest concentration being contained in vinyl records. It is also found in cigarette smoke at concentrations that depend on the chloride concentration of the tobacco (137). VCM has been produced in the USA for $>70$ years, $\sim 6.2$ million tons were produced in 2001 (9). In 2005, 35 million tons were produced worldwide (52). Approximately 40,000 workers in Europe and 80,000 in the USA have been potentially exposed to VCM prior to 1997 (137). Prior to the adoption of environmental regulations, exposure levels were as high as $13,000 \mathrm{ppm}$ (138). In developed countries, where strict controls are now in place, current levels of occupational exposure are $<1$ ppm (139).

Detailed reports of VCM toxicity first appeared in the 1970s. VCM is causally associated with a form of non-cirrhotic portal hypertension associated with sinusoidal endothelial damage and ASL. VCM and PVC production involve the use of various chemicals, a number of which are carcinogenic, such as ethylene dichloride (140). More recently it has been suggested that VCM also results in HCC (9).

VCM is rapidly absorbed following inhalation and is primarily metabolized by the liver (141), resulting in generation of chloro-ethylene oxide. This is a reactive intermediate metabolite detoxified by conjugation with glutathione or via aldehyde dehydrogenase, which can also form mutagenic DNA adducts (142). VCM vapor induces DNA strand breaks, sister chromatid exchanges (SCE), micronucleus (MN) formation, and other chromosomal aberrations. VCM has been demonstrated to be mutagenic in a number of different in vitro assays (9).

A wide range of experimental and epidemiological studies have demonstrated the carcinogenicity of VCM in animal models and humans (142), resulting in its classification by the IARC as a Group 1 carcinogen $(135,136)$. There is considerable evidence for the association of occupational VCM exposure and liver cancer $(143,144)$, as well as tumors of the brain (55), lung (145), and hemo-lymphopoietic system (146). VCM results in the development of ASL, but it may also have a toxic impact on the liver, leading to cirrhosis and HCC (57). It has a direct negative effect on the liver (134) in combination with other toxic agents $(57,147)$. In addition, in VCM-exposed workers with HCC, a high prevalence of Kirsten rat sarcoma viral oncogene homolog (KRAS)2 mutations (58) and a characteristic p53 mutation pattern (58) have been identified. In ASL, a distinctive GGC to GAC mutation is observed in the KRAS2 gene at codon 13, or less often at codon 12, where it is also $\mathrm{G}$ to $\mathrm{A}(148,149)$. The p53 gene mutations that are observed in VCM-induced ASL occur at multiple positions on the p53 gene and do not appear to be characteristic of VCM exposure $(56,150)$. In an in vivo study $\mathrm{HCC}$ was induced in rats by VCM inhalation or oral feeding (151-155), however, HCC was not induced when exposure was via subcutaneous or intraperitoneal injection $(149,156-159)$. Feron et al $(160,161)$ and Til et al (159) also described dose-response associations between VCM exposure and HCC development.

An association between VCM exposure and HCC or cirrhosis mortality has also been reported in a cohort of workers at one of the plants that was surveyed in a previous study (141). Wong et al $(60,61)$ examined mortality rates in 3,293 PVC factory male workers, and observed an increased SMR for malignant neoplasms of the liver (SMR, 1.78, 95\% CI, 1.15-2.62). A meta-analysis of studies of occupational exposure to VCM and its association with cancer mortality (143) also observed that workers were at an increased risk of HCC. Overall, epidemiological and experimental studies have reported sufficient data for an association between exposure to inhaled VCM and HCC $(62,63,65,140)$. Thiodiglycolic acid is the predominant VCM metabolite detected in the urine of occupationally exposed subjects.

Organic solvents $(O S)$. OS are a group of volatile compounds or mixtures that are carbon-based solvents. Common OS include halogenated, cyclic, aromatic or aliphatic hydrocarbons, ketones, amines, esters, alcohols, aldehydes, and ethers. Numerous OS are found as mixtures of chemical compounds (162-165).

OS are used to extract, dissolve, or suspend substances, such as waxes, fats and resins, which are usually water insoluble. Solvents are used in paints, glues, adhesives, degreasing/cleaning agents, coatings and in the production of dyes, textiles, agricultural products polymers, plastics, and pharmaceuticals $(162,163)$. Tens of millions of workers in the USA and Europe are estimated to be exposed to organic solvents (15).

A high risk of mortality from biliary duct and liver cancer has been observed among painters and workers exposed to OS in a meta-analysis of cohort investigations $(15,166)$, even though in numerous studies the solvent-specific risk may not be easily estimated due to concurrent exposure to various xenobiotics (68). However, few studies have addressed the association between exposure to OS and the risk of liver cancer, with the exception of perchloroethylene (PCE) and trichloroethylene (TCE).

TCE (CAS no. 79-01-6) is widely used in dry cleaning and paint stripping, in industrial applications as an OS for metal 
degreasing, and in the manufacturing of chlorinated chemical compounds (69). Workers employed in a range of industries, including aircraft/aerospace maintenance or manufacture, shoe manufacturing, electronics, printing, painting, dry cleaning, metal degreasing, and chemical industries are at risk of TCE exposure $(167,168)$. TCE is a common, persistent environmental pollutant that has been detected in over one third of hazardous waste sites and in $10 \%$ of groundwater sources (66). Although exposure has been associated with a variety of adverse health effects, it is particularly toxic for the kidneys and the liver (169). Experimental research has documented high risks of liver, lung, kidney, and hematopoietic neoplasms in TCE-exposed animals $(67,170)$. In particular, chronic exposure has been demonstrated to induce renal cell carcinoma and HCC in rats and mice, respectively (171). In 2012, IARC, based on evidence of TCE exposure and kidney cancer, recognized TCE as a definite human carcinogen (Group 1) (172,173). A recent study has also reported a markedly higher rate of liver cancer in TCE-exposed workers compared with non-exposed individuals (174).

The carcinogenic MOA of TCE remains to be elucidated (175). A mutagenic MOA has been suggested for TCE-induced kidney tumors, possibly associated with the genotoxic TCE metabolites that form via glutathione conjugation in the kidney (176). Despite reports of liver carcinogenicity in experimental animals and in human epidemiological studies $(171,174,177)$, the exact underlying molecular mechanism(s) involved in TCE-induced hepatocarcinogenesis require further elucidation. Biotransformation occurs in the liver predominantly via the cytochrome P450 (CYP) enzymes. Its major metabolite is tricarboxylic acid (TCA) $(176,177)$. However, neither TCE nor TCA have been confirmed to be mutagenic (177), thus, a role for non-genotoxic mechanisms in TCE hepatocarcinogenesis has recently been suggested (72).

Non-genotoxic carcinogens induce cancer via a variety of mechanisms, including alteration of cell proliferation and apoptosis, peroxisome proliferation, and epigenetic changes. An altered balance between proliferation and apoptosis is a characteristic of tumorigenesis, and abnormal liver regeneration may be a common mechanism for hepatocarcinogenesis, independent of etiology $(73,74)$. Hyperactivation of peroxisome proliferator activated receptor (PPAR) $\alpha$ has been suggested to contribute to liver cancer development in rodents (176).

Jiang et al (75) described the dysregulation of a number of genes involved in PPAR, proliferation, and apoptosis signaling pathways in the liver of mice exposed to $1,000 \mathrm{mg} / \mathrm{kg}$ TCE. Notably, liver expression of marker of proliferation Ki67, a cell proliferation-associated nuclear marker, increased in a dose-dependent manner. TCA is a ligand for PPAR, and peroxisome proliferation has been reported in mouse liver following TCE exposure $(71,178)$. Hepatocyte hyperplasia and increased liver-to-body weight ratio have also been frequently described in TCE-exposed mouse liver $(71,179)$.

TCEhas been demonstrated toinduce mRNAoverexpression of three homologous recombination (HR)-associated genes, Rad51, Rad51b, and Rad51ap1, in a dose-dependent manner. HR catalyzed by Rad51 is a key mechanism in the elimination of DNA double-strand breaks, and HR dysfunction results in inappropriate recombination and genomic instability (180). It has recently been reported that TCE exposure may affect the expression of HR-associated genes in mouse liver, which may lead to HR hyperactivity, genome fragility, and tumorigenesis (75).

$\mathrm{HCC}$ is currently recognized as a genetic and an epigenetic disease. Mounting experimental evidence indicates that epigenetic regulation of gene expression by DNA methylation, histone modifications and microRNAs are key at all stages of liver carcinogenesis (181).

Jiang et al (75) also found that TCE induced marked changes in the expression of genes involved in key signaling pathways, including regulation of DNA methylation, and that it may result in hypo- and hypermethylation in the promoter regions of single-copy genes, contributing to aberrant transcriptional changes. TCE may also induce DNA hypomethylation and mRNA overexpression of c-jun and c-myc, two oncogenes that are critical promoters of cellular proliferation in the mouse liver (182). Dysregulated expression and activation of the two genes is often detected in cancer $(183,184)$.

PCE, also known as tetrachloroethylene (CAS no. 127-18-4), occurs in a number of occupational settings where organic solvents are used, particularly the dry cleaning industry and textile processing, as a chemical intermediate, and for vapor degreasing in metal cleaning operations (185). Exposure in the dry cleaning industry is primarily via inhalation and dermal contact, and is highest during machinery operation (186). A previous study of dry cleaning workers exposed to PCE have indicated there are associations with multiple types of cancer, particularly bladder cancer, non-Hodgkins lymphoma, and multiple myeloma. There is also limited evidence suggesting associations with esophageal, kidney, cervical, and breast cancer (177). An increased risk of liver cancer has been reported among workers and experimental animals exposed to PCE $(70,187,188)$.

Animal studies have demonstrated an increased incidence of liver tumors in mice following PCE inhalation and gavage, and of kidney and mononuclear cell leukemia in rats following inhalation exposure $(76,172,189)$.

PCE has been classified by the US Environmental Protection Agency (EPA) as likely to be carcinogenic to humans by all routes of exposure, based on suggestive evidence from epidemiological studies and on conclusive evidence demonstrated in rats developing mononuclear cell leukemia and mice indicating increased incidence of liver tumors. it has also been designated as probably carcinogenic to humans (Group 2A) in industry dry cleaners by the IARC $(167,172)$.

A previous study (68) conducted on workers in Northern Italy assessed the association between occupation and risk of liver cancer and observed a slightly increased HCC risk in workers exposed to toluene and xylene. Results indicated that occupational exposure exerted a limited effect in liver carcinogenesis and that prolonged exposure to OS, such as toluene and xylene, may increase the risk. The biological indicator of occupational exposure to TCE is urinary trichloroacetic acid.

1,1,1-Trichloro-2,2-bis(p-chlorophenyl)-ethane (DDT) and other pesticides. Investigations into occupational exposure to pesticides have predominantly focused on agriculture, particularly product distributors, mixers and loaders, applicators, 
bystanders, and workers re-entering the fields shortly following treatment.

Approximately 500,000 tons of active pesticide ingredients are used annually and $>20,000$ pesticide products are currently sold in the US (77). According to EPA estimates, 10,000-20,000 physician-diagnosed pesticide poisonings occur each year among the 2 million agricultural workers in the US (77). Agricultural workers, groundskeepers, pet groomers, fumigators, and a variety of other jobs are at risk of exposure to a multiple products, including fungicides, herbicides, insecticides, rodenticides, and sanitizers. Toxicity depends on the compound family, and is generally greater for the older compounds. In humans, pesticides are responsible for acute poisonings, as well as long-term health effects, including cancer and adverse effects on reproduction $(78,79,190)$.

A number of epidemiological studies have suggested that pesticides may be important in HCC development among workers employed in the farming industry (80-82). Various pesticides, such as chlordane, dieldrin, lindane, heptachlor and pyrethrins $(139,191,192)$ are established as liver carcinogenic in animal models. However, few investigations have addressed the association between exposure to pesticides and the risk of liver cancer, except for DDT (CAS no. 50-29-3) (137,193).

DDT has been implicated in liver damage and hepatocarcinogenesis in animals $(83-85,194)$. Based on animal studies, DDT and its most persistent metabolite, 1,1-dich loro-2,2-bis(p-chlorophenyl)-ethylene (DDE), have been classified by the IARC as possibly carcinogenic to humans (Group 2B) (195), and DDT has been defined as a reasonably anticipated human carcinogen by the US National Toxicology Program (NTP) $(196,197)$.

DDT is an insecticide that was largely used in the past, however, in the 70s, numerous developed countries banned it due to its toxic effects and environmental persistence (196). China banned it in 1983, but production is still permitted; annual production is 4,000-6,000 metric tons, employed to make dicofol (86) and for uses in agriculture and the control of malaria, leishmaniasis and termites in numerous African and Asian countries (87). WHO recommendations and guidelines allow using DDT to control disease vectors until suitable alternatives become available (198). The general population is exposed to DDT primarily via food ingestion, while occupational exposure is predominantly due to inhalation and dermal contact $(88,89)$. Although DDT is preferentially stored in adipose tissue, the majority of DDT-associated compounds in blood are bound to proteins (90). The half-life of DDT in humans is $\sim 7$ years, whereas the half-life of DDE is notably longer (193). DDT and DDE induce a wide range of adverse health effects in humans, including reproductive, neurological, carcinogenic, and developmental disorders (88). Like a number of other chlorinated compounds, DDT leads to liver cancer in laboratory animals $(83-85,90,194,199,200)$. A risk of liver cancer has also been described in workers exposed to DDT (91).

Previously, three studies on human patients have addressed the association between DDT and/or DDE and the risk of developing HCC $(92,93,193)$. A notable correlation has been observed between quantity of DDE in adipose tissue and liver cancer mortality (94). The risk of liver cancer was higher among Chinese men with higher DDT blood levels (92).
Current epidemiological studies indicate that DDT may be a risk factor for HCC (92). However, data interpretation must be considered as consistency among various studies is rare, particularly with regards to their methodological limitations $(88,93,201,202)$. The association between DDT and HCC may also be associated with the endocrine disruption properties of the compound. DDT exerts estrogenic effects, whereas p,p'-DDE has anti-androgenic effects (193). A previous study of endocrine-disrupting chemicals in male mice demonstrated that DDT had an upregulating effect on a number of genes including CYP3A11, one of the hepatic CYP family members involved in inflammatory responses in the liver (203). DDT and DDE have been demonstrated to affect the immune response (204). It is difficult to interpret the role of serum DDT and DDE levels in HCC development in a population with a high prevalence of chronic HBV infection (193). According to Zhao et al (93), HBV infection and DDT exert a synergistic effect, promoting the development of HCC.

DDT promotes aflatoxin B1 (AFB1)-induced hepatocarcinogenesis in rats (205). This effect may be particularly important in areas with high HCC risk, such as China and Africa, where AFB1 has strongly been associated with HCC. AFB1 is a known hepatocarcinogen in certain areas of China, and combined with DDT has been reported to exert a synergistic effect on HCC development (93).

Health surveillance involves biological monitoring of exposed workers by search for specific exposure indicators, in this case serum concentration of DDT (p,p'-DDT) and DDE (p,p'-DDE).

$N$-Nitrosamines. $\mathrm{N}$-Nitrosamines are chemical compounds in which the key feature of $N$-nitroso compounds is the $\mathrm{N}-\mathrm{N}=\mathrm{O}$ structure. $R_{1}$ and $R_{2}$ groups attached to the amine nitrogen may range froma single hydrogenatomtomore complex chemicalsubstituents, including ring structures that incorporate the nitrogen atom (206). $N$-Nitrosamines include: $N$-Methyl- $N$ '-nitro- $N$-nitrosoguanidine (CAS no. 70-25-7); $N$-nitrosodi- $n$-butylamine (CAS no. 924-16-3); $N$-nitrosodiethanolamine (CAS no. 1116-54-7); $\mathrm{N}$-nitrosodiethylamine(CASno.55-18-5); $\mathrm{N}$-nitrosodimethylamine (CAS no. 62-75-9); $N$-nitrosodi- $n$-propylamine (CAS no. 621-64-7); $N$-nitroso- $N$-ethylurea (CAS no. 759-73-9); 4-(N-nitrosomethylamino)-1(3-pyridyl)-1-butanone (CAS no. 64091-91-4); $N$-nitroso- $N$-methylurea (CAS no. 684-93-5); $N$-nitrosomethylvinylamine (CAS no. 4549-40-0); $N$-nitrosomorpholine (CAS no. 59-89-2); $N$-nitrosonornicotine (CAS no. 16543-55-8); $N$-nitrosopiperidine (CAS no. 100-75-4); $\mathrm{N}$-nitrosopyrrolidine (CAS no. 930-55-2); and $\mathrm{N}$-nitrososarcosine (CAS no. 13256-22-9).

From 1981 to 1991, the US NTP conducted a number of investigations to characterize and assess the toxicological potential and carcinogenic activity of $N$-nitrosamines in laboratory animals (rats and mice) (206). Experimental results indicated that all $\mathrm{N}$-nitrosamines were reasonably anticipated to be human carcinogens on the basis of ample evidence of carcinogenicity from animal studies. In fact, all had the capacity to result in tumors 'in several species of experimental animals, at several different tissue sites, and by several different routes of exposure' $(206,207)$. Tumors were 
predominantly observed in the liver, kidneys, respiratory and upper digestive tracts $(95,206,208)$. HCC was induced by all $\mathrm{N}$-nitrosamine compounds, however, data extension to other species and quantitative risk analyses for humans require broader investigation.

Human exposure to nitrosamines can result from formation of $N$-nitroso compounds in food during storage, preparation, cooking, or else in vivo, usually in the stomach (209). Nitrosamines, or their precursors, are commonly found in agricultural chemicals, detergents, tobacco, rust inhibitors, cutting fluids, plastics, tanned leather goods, solvents, pharmaceuticals, textiles, rubber additives, and cosmetics (201-214). Usually, they form from constituents of the foods or products that are naturally present, such as protein amines; less commonly, they are added to food during production, like nitrates or nitrites added to meat as preservatives.

Nitrosamines are also produced in research laboratories, in rubber and tire manufacturing processes, and they may be found as contaminants in the final rubber product (24). Certain nitrosamines have been observed to be effective for a variety of purposes, including antimicrobial ( $N$-nitrosomorpholine) or chemotherapeutic agents ( $N$-nitrosodimethylamine and $\mathrm{N}$-nitroso-N-methylurea) in conjunction with other agents; herbicides ( $N$-nitrosodimethylamine and $\mathrm{N}$-nitrosodi-n-propylamine); additives to soluble and synthetic metalworking fluids (N-nitrosodiethanolamine); solvents or gasoline and lubricant additives ( $N$-nitrosodiethylamine); antioxidants, stabilizers in plastics, fiber industry solvents, and copolymer softeners, and to increase dielectric constants in condensers $(95,206,208)$.

Occupational exposure may occur via inhalation or dermal contact where $N$-nitrosamines are produced or used in manufacturing, or are employed as herbicides, in research, and in clinical testing for use as chemotherapeutics. Healthcare workers may be exposed during therapeutic agent preparation, administration or cleanup $(95,206)$. Occupational exposure to $N$-nitrosodiethylamine has been suggested in laboratory, chemical research, copolymer, and lubricant workers $(95,208)$.

A review of large body of evidence from epidemiological studies of workers employed in the rubber manufacturing industry observed a marked excess cancer risk at a variety of sites (25). The IARC has recently classified occupational exposures in the rubber-manufacturing industry as carcinogenic to humans (Group 1) $(24,135)$. According to exposure assessment studies such workers may be exposed to different airborne carcinogenic and/or genotoxic chemicals, including certain aromatic amines, polycyclic aromatic hydrocarbons, and $N$-nitrosamines, although current data do not support a causal association of particular substances/classes of chemicals or occupations with cancer or genotoxic risk. In environmental surveys of a number of European rubber factories De Vocht et al (26) and Jönsson et al (27) found average $\mathrm{N}$-nitrosamine levels well below current regulatory limits, although exposure has not completely been eliminated and accidental high exposures still occur. High urinary levels of $N$-nitrosamines have been detected in exposed workers (28). Recent studies have reported a strong correlation between $\mathrm{N}$-nitrosamine exposure and telomere shortening among workers in the rubber industry. Telomeres are critical to maintain chromosome integrity, and telomere length abnormalities are associated with carcinogenesis $(215,216)$.

Health surveillance envisages biological monitoring of exposed workers via the search for specific exposure markers, in this case urinary $\mathrm{N}$-nitrosamines.

Dioxin-like compounds (DLC). DLC are byproducts of a variety of industrial processes that include polychlorinated dibenzo-p-dioxins (PCDD) and polychlorinated dibenzofurans (PCDF), or furans and dioxin-like polychlorinated biphenyls (217).

PCDD are formed inadvertently, sometimes in combination with PCDF, as contaminants during production of chlorophenols and chlorophenoxyherbicides (218). PCDD and PCDF may also be produced in thermal processes, including incineration and metal-processing (135).

PCDD are everywhere in the environment. Occupational exposures to PCDD have occurred since the 1940s following the production and use of chlorophenols and chlorophenoxy herbicides, and higher exposures have sometimes occurred following accidents in these industries (29).

The most toxic and best investigated member of the dibenzo-p-dioxin family of isomers is 2,3,7,8-tetrachlorodibenzo-p-dioxin (TCDD) (219).

TCDD (CAS no. 1746-01-6) is a Group 1 IARC carcinogen, thus, is classified as carcinogenic to humans $(135,218)$. IARC recently classified 2,3,4,7,8-pentachlorodibenzofuran (PeCDF) (CAS no. 57117-31-4) and 3,3',4,4',5-pentachlorobiphenyl (PCB 126; CAS no. 57465-28-8) as carcinogenic to humans (Group 1). There is limited or no evidence of carcinogenicity in experimental animals for numerous other dibenzo-p-dioxins, including PCDD and 2, 7-DCDD (218).

TCDD is a contaminant of materials that include 2,4,5-trichlorophenol (TCP), 2,4,5-trichlorophenoxyacetic acid (2,4,5-T), and 2-(2,4,5-trichlorophenoxy) propionic acid (Silvex). Occupational exposure may take place following contact with materials used or from past workplace contamination $(135,220)$.

PCDF are commercially manufactured exclusively for scientific purposes. Their release into the environment is predominantly from combustion. Based on congener-specific profiles, all combustion sources produce 2,3,7,8-substituted PCDD and PCDF, including PeCDF. The latter substance is the major congener emitted from cement kilns burning hazardous waste ( $20 \%$ of total congener emission). Furthermore, major sources of PeCDF are metal manufacturing, chemical processing [production of chlorophenols, polychlorinated biphenyls (PCB), and vinyl chloride]; and pulp bleaching $(218,221,222)$. PCB mixtures, including PCB 126, were produced for use as dielectric insulating fluids for transformers and capacitors for the electrical industry between 1929 and 1977 (135). Inhalation and dermal contact are the major routes of occupational exposure (220).

The major sources of TCCD environmental contamination are municipal incinerators, production and use of pentachlorophenol as a wood preservative, and use of chlorine for bleaching in pulp and paper mills (223). Additional sources include emissions from iron and steel manufactures, burning of various fuel types (for example, wood, diesel and heating 
oil), backyard burning of household waste, electric power generation, and tobacco smoking $(223,224)$. Natural sources include forest fires and volcanoes (225).

TCDD usually persists as a pollutant in TCP in small, variable quantities $(0.07-6.2 \mathrm{mg} / \mathrm{kg})(226)$. TCP has chiefly been used to produce phenoxy herbicides 2,4,5-T and Silvex. However, occupational TCDD exposure may occur during TCP production, in the treatment of contaminated sites, from waste materials (such as reclaimed oil), or from cleanup following fires in transformers containing polychlorinated aromatics.

In animal studies, a wide range of exposure concentrations has been demonstrated to induce various systemic effects, such as carcinogenesis, immunological alteration, and teratogenesis. In humans exposed to TCDD-contaminated materials, the compound has been reported to result in chloracne and metabolic disorders (219). The carcinogenic and hepatotoxic effects of TCDD appear to be gender-dependent, as female rats proved to be more susceptible than male rats (223). A two-year cancer bioassay by the US NTP, evaluating the hepatotoxic and carcinogenic properties of TCDD in female rats $(32,220,227)$, indicated that chronic exposure (100 ng/kg/day) for 104 weeks induced a notable increase in the incidence and range of non-neoplastic and neoplastic liver lesions $(220,227)$. Non-neoplastic lesions included hepatocyte hypertrophy, pigmentation, bile duct hyperplasia, oval cell hyperplasia, diffuse fatty changes, necrosis, inflammation, cholangiofibrosis and numerous others. Neoplastic lesions included HCC.

In in vivo studies, oral PeCDF administration induced a marked proportional rise of cholangiocarcinoma (CLC) and hepatocellular adenoma (HCA) $(32,227)$, whereas subcutaneous injection increased the number of focal liver damage sites in female rats (228), and the multiplicity of HCC and liver hyperplastic nodules in male rats (229). Oral administration of PCB 126 resulted in a notably higher incidence of HCA and CLC $(32,226)$. The most important epidemiological studies of TCDD carcinogenicity were cohort studies of herbicide producers and users in the US, the Netherlands and Germany, and of the residents of a contaminated area at Seveso, Italy $(218,230-233)$. All found an increased risk for lung cancer, soft tissue sarcoma and non-Hodgkin lymphoma, primarily in the more heavily exposed sub-groups $(135,218)$.

The majority of the effects of TCDD are mediated by aryl hydrocarbon receptor (AhR) (234). In a previous study of AhR knockout mice, acute TCDD toxicity was demonstrated to depend on AhR functionality. This suggests that the hepatotoxic effects of TCDD and similar DLC are mediated by AhR, and that gene expression changes resulting from its activation are likely to be important for toxicity (219). Upon binding to its ligands, cytoplasmic AhR, which is bound to multiple chaperone proteins $(235,236)$, undergoes a conformational change that results in its dissociation from chaperone proteins and ins translocation into the nucleus, where it dimerizes with its partner AhR receptor nuclear translocator (237). Binding of the heterodimer to xenobiotic-responsive elements in target gene promoters results in upregulation of these genes. TCDD is well known to upregulate the genes encoding the enzymes involved in xenobiotic metabolism, such as CYP1A1 (238). However, increasing data indicates that AhR controls the expression of a variety of genes not associated with xenobiotic metabolism $(239,233)$. In human lymphocytes, TCDD, a potent AhR agonist, markedly increased the frequency of SCEs (234). AhR knockdown has resulted in decreased proliferation and/or invasion and migration of liver cancer cell lines. A previous in vivo study demonstrated that mice overexpressing constitutively active AhR exhibited more liver cancer, suggesting a pro-oncogenic role for AhR (235).

The receptor-mediated MOA for human TCDD-associated carcinogenesis is suggested to include 2,3,4,7,8-PeCDF and PCB 126 as leading to cancer in humans. The predominant mechanism is promotion of carcinogenesis via activation of cell replication and cellular senescence, and apoptosis alteration via the AhR. These congeners, through activation of an array of metabolic enzymes, increase the risk of oxidative stress as an indirect starter of tumorigenesis, which makes these congeners carcinogenic. Preservation of the AhR and associated signaling pathways across species strongly support this MOA in humans (135).

The health surveillance for TCDD, PeCDF and PCB involves biological monitoring of exposed workers using assessment of blood concentrations of TDCC, PeCDF, and $\mathrm{PCB}$, respectively.

Polychlorinated biphenyls (PCB). PCB (CAS no. 1336-36-3) comprise a class of synthetic chlorinated aromatic hydrocarbons. They generally have a biphenyl molecule with $\geq 1$ or up to 10 chlorine atoms $\left(\mathrm{C}_{12} \mathrm{H}_{10-\mathrm{x}} \mathrm{Cl}_{\mathrm{x}}\right)$. $\mathrm{PCB}$ are mixtures of 209 congeners, which differ in the number and position of chlorines on the biphenyl rings (236). However, only 130 have been described in marketable PCB mixtures (237). Due to their chemical stability, PCB are ubiquitous environmental and human contaminants.

PCB were extensively produced in the USA from 1929 to 1977 . Their stability, dielectric properties, oxidation resistance, and incombustibility prompted their use in electrical insulation, heat exchange, and lubricating fluids. PCB were also blended with other chemicals, such as plasticizers and fire retardants, and used in a variety of products, including caulks, adhesives, plastics, and carbonless copy paper (137). Production peaked in the 1970 s and steadily declined thereafter, as numerous countries worldwide banned their use or restricted production $(238,239)$.

Occupational exposure is predominantly via inhalation and dermal contact. Commercial PCB mixtures vary from colorless to dark brown oils, and from viscous liquids to sticky, resinous semisolids. Although PCB evaporate slowly at room temperature, their volatility markedly increases with minimum rises in temperature. Equipment that contains PCB can overheat and vaporize notable quantities of these compounds, creating an inhalation hazard that can be amplified by poor ventilation $(240,241)$.

As PCB-containing products are no longer manufactured, occupational exposure is no longer relevant except in relation to maintenance or repair of old PCB-containing material, such as old industrial equipment (welding equipment), medical equipment (x-ray machines), household appliances (refrigerators, microwaves and TV sets) (237,242,243), accidents involving such equipment $(240,244)$, waste-site cleanup or disposal activities $(242,245)$, and repair or removal of old construction materials, including plaster, paint, and caulk. 
PCBs accumulate in adipose tissue, thus potentially causing long-term effects (137). Animal studies by the US NTP and other investigators have documented that PCB is important in the development of liver disease $(226,246-249)$ and that the liver is their main target organ (137).

In vivo data indicates that $\mathrm{PCB}$ induces pre-neoplastic lesions and HCC in a dose-and-time-dependent manner, however, its MOA is unknown (138). A previous study has associated PCB exposure with high levels of human alanine transaminase as well as increased hepatic expression of genes involved in apoptosis, inflammation, and oxidative stress (247).

The 209 PCB congeners greatly vary in their propensity for metabolic attack, the first line of which is mono-oxygenation by members of the CYP superfamily. This can theoretically produce $>837$ possible monohydroxylated products $(250)$. It has been hypothesized that enzyme hydroxylation may occur via a 'direct insertion' mechanism or via the intermediacy of an arene oxide (251-255). The autoxidation/enzymatic oxidation of a PCB hydroquinone may produce reactive oxygen species (ROS), such as oxygen ions and peroxides $(256,257)$. ROS are considered to be important in PCB-associated genotoxicity (258). A number of higher chlorinated PCB congeners are effective inducers of xenobiotic metabolizing enzymes (259), a change that may alter the metabolism of endogenous or exogenous compounds. For instance, PCB induce CYP in the liver, which may change the metabolism of endogenous estrogen to more dangerous estrogen catechol derivatives (260) or ROS producing estrogen quinones (261). In a previous study, $\mathrm{PCB} 153,138,101$, and 118 induced $\mathrm{MN}$ in fish cells in vitro (262) and PCB-contaminated soil from industrial or irrigation sites induced $\mathrm{MN}$ in plant species $(263,264)$. Para-quinone induced MN predominantly by chromosome breaks. However, monohydroxylated products and, to a lesser extent, other metabolites, induced MN largely by chromosome loss, pointing at different genotoxicity mechanisms. The highly reactive quinone may interact with DNA directly, or with DNA maintenance proteins like topoisomerase, leading to chromosome breaks. The other compounds may react with the cytoskeleton or with other proteins involved in chromosome distribution. Numerous PCB congeners and PCB3 p-quinone induce telomere shortening, the former likely by reducing telomerase activity, the latter likely via ROS generation (265-267). Chromosome breaks and rearrangements have been described in human lymphocytes exposed to PCB77 or PCB153 $(268,269)$ In in vivo studies in rats $(270)$, lower chlorinated PCB were able to initiate hepatocarcinogenesis.

By contrast, there is little data regarding PCB in human liver disease. Over a 24-year follow-up subsequent to the Yu-Cheng accident (Taiwan), a number of people exposed to cooking oil contaminated with PCB developed cirrhosis and other chronic liver disorders $(271,272)$. Epidemiological investigations reported a higher mortality from HCC in subjects with heavy PCB exposure (273). Previous studies on PCB-exposed workers, including cohorts of electrical capacitor and transformer manufacturing workers, have observed a notable association between doses of PCB exposure and liver cancer mortality; however, the role of PCB in human hepatocarcinogenesis is still debated (274-277).

PCB were earlier classified as IARC Group 2A as probable human carcinogens based on evidence of carcinogenicity in animals and limited evidence from human studies (278). The subsequent classification of PCB 126 as a human carcinogen (135) prompted a reassessment of all PCB in 2013 (236,279). Epidemiological studies associating PCB exposure with melanoma, and animal studies reporting exposure-associated tumors in the lung, liver and oral mucosa, were judged to be sufficient evidence for carcinogenicity in humans and experimental animals, leading to the classification of PCB as IARC Group 1 (279,280). Health surveillance requires biological monitoring of exposed workers by assessment of plasma PCB.

Polybrominated biphenyls $(P B B)$. PBB are a class of biphenyl compounds where one to 10 hydrogen atoms are replaced by bromine. Hexabromobiphenyl $\left(\mathrm{C}_{12} \mathrm{H}_{4} \mathrm{Br}_{6}, \mathrm{CAS}\right.$ no. 6355-01-8), is the predominant component of the commercial PBB mixtures tested in animal carcinogenicity studies, including FireMaster FF-1 (281). The NTP has characterized and tested the toxic potential and carcinogenic activity of $\mathrm{PBB}$ in laboratory rats and mice. PBB have been defined as reasonably anticipated human carcinogens based on sufficient evidence of carcinogenicity from studies in experimental animals. Oral exposure to PBB resulted in liver tumors in mice and rats. Administration of FireMaster FF-1 by stomach tube led to HCC in mice and rats of both genders, and CLC in rats of both genders (281).

No epidemiological studies have evaluated the association between human cancer and specific exposure to PBB. The IARC reviewed the available evidence in 1986 and concluded that there were no informative studies. Since then, a case-control study of participants in a PBB exposure registry in Michigan observed a marked exposure level-associated increases, based on serum PBB, in lymphoma and digestive system cancer (282). Other studies, however, are uninformative.

Two PBB isomers, hexaoctabromobiphenyl (CAS no. 61288-13-9), and decabromobiphenyl (CAS no. 13654-09-6), were formally commercially produced. In 2009, decabromobiphenyl was produced in China and Europe and was available on the US market (283). No suppliers for either hexabromobiphenyl or octabromobiphenyl are currently found worldwide (283). PBB have largely been replaced by polybrominateddiphenyl ethers (PBDE) as fire retardants in textiles, electronic equipment, and plastics (284). However, PBB have been detected as impurities in PBDE.

Residues remaining in and around facilities that formerly manufactured, processed, or produced PBB-containing goods are current sources of exposure. Workers at companies that manufactured PBB may have been exposed by skin contact, inhalation or unintentional ingestion.

The conclusions of the IARC meeting on PBB are summarized in a Lancet Oncology report (279). The full report will be issued as volume 107 of the IARC monograph series. There was 'inadequate' epidemiological evidence for PBB carcinogenicity, however, 'sufficient' evidence in experimental animals, as well as data indicating that their toxic effects and carcinogenic potential involve a number of the same pathways as PCB, resulted in their classification as 'probably carcinogenic to humans' (Group 2A) (280).

Health surveillance requires biological monitoring of exposed workers by determination of PPB serum concentration. 
Chloral and chloral hydrate. Chloral (CAS no. 75-87-6) is produced by chlorinating acetaldehyde or ethanol in acidic solution (278). It has predominantly been used to produce DDT and other insecticides, namely methoxychlor, naled, trichlorfon, dichlorvos and the herbicide TCA (285). Chloral has also been used to produce rigid polyurethane foam $(167,209)$ and to induce swelling of starch granules at room temperature (286).

Chloral hydrate (CAS no. 302-17-0) has been used since the 1870s as a hypnotic, chiefly for the short-term treatment of insomnia, to alleviate anxiety, and to induce sedation. It is also an ingredient in Hoyer's solution, which is used in microscopy to mount organisms, such as bryophytes, ferns, seeds, and arthropods (172).

Chloral has been detected during spraying and casting of polyurethane foam (287), has been identified as a TCE autoxidation product during vegetable oil extraction, and observed in the output of etching chambers in semiconductor processing (288). Even though chloral is employed as an intermediate in the production of insecticides and herbicides, chloral hydrate is found in swimming pools as part of a mixture of by-products resulting from water disinfection by chlorination. There is no epidemiological evidence of cancer risks associated specifically with these by-products (289).

An in vivo study on mice, oral administration of chloral in water induced liver nodules, hyperplastic nodules and HCC after 92 weeks (290). Significant increases in HCC incidence have been observed in treated mice surviving 104 weeks $(291,292)$.

The association between numbers of chloral hydrate prescriptions and overall cancer has been examined in a case-control study, but no notable patterns have been observed (172).

Strong evidence suggests that chloral hydrate is genotoxic in mammals and other species in vivo and in vitro, inducing mutations, chromosomal aberrations, and MN formation. One study observed a marked increase in MN formation in peripheral blood lymphocytes in infants exposed to oral chloral hydrate (172). Adverse health effects have been reported for the liver, kidney, and central nervous system (CNS), suggesting that these organs are potential targets for the chemical (171).

The MOA remains unknown, however, multiple genotoxicity mechanisms have been hypothesized, such as an increase in cell proliferation, induction of peroxisome proliferation response, and disruption of gap-junction intercellular communication. Evidence for non-genotoxic mechanisms in liver cancer is poor (172). Chloral hydrate is used as sedative for humans and veterinary application. CNS is a target tissue, however, the relevance of neurotoxicity to cancer is unknown (172).

Human adverse effects resulting from chloral hydrate depend on inter-individual variability. The major metabolic enzymes alcohol dehydrogenase and aldehyde dehydrogenase are linked to their common polymorphisms that result in differences in alcohol metabolism. The consumption of alcoholic beverages may also be a susceptibility factor, as the enzymes are also involved in the biotransformation of chloral hydrate. With regards to chloral and chloral hydrate, IARC reported inadequate evidence for the carcinogenicity of humans, but sufficient evidence in animals. The two compounds are likely Group 2A carcinogens.

The biological indicator of occupational exposure to both chemicals is chloral hydrate in the blood and urine.

ortho-Toluidine (o-toluidine). o-Toluidine (CAS no. 95-53-4) is used for the production of herbicides, such as metolachlor and acetochlor, dyes and pigments, including azo pigment dyes, triarylmethane dyes, sulfur dyes, and indigo compounds, and for synthesis of rubber, pharmaceuticals and other chemicals (135). In diagnostic laboratories it is used as reagent for glucose analysis and for tissue staining $(293,294)$.

Occupational exposure may occur during manufacturing/production of dyes, pigments and in rubber chemicals via inhalation or skin contact. Laboratory and medical staff may be exposed when using it for staining tissues $(295,296)$. Other possible exposure may result from the use of certain hair dyes, the local anesthetic prilocaine and tobacco smoke $(297,298)$.

Sorahan et al $(299,300)$ reported an excess of bladder-cancer risk in UK workers exposed to o-toluidine. Epidemiological studies indicate significant associations between o-toluidine exposure and bladder cancer (135).

Oral administration to male and female rats has been reported to cause an increased HCC incidence (301). There is sufficient evidence for its carcinogenicity in humans and animals (IARC Group 1). The biological indicator of occupational exposure is urinary o-toluidine concentrations in post-shift samples.

\section{4, 4'-Methylene bis (2-chlorobenzenamine) (MOCA). MOCA} (CAS no. 101-14-4) is used for polyurethane pre-polymers in the manufacture of castable urethane rubber products. In addition, it is used as a model compound to study carcinogens $(295,302,303)$. Occupational exposure can occur during its production and with its use in the polyurethane industry. The common occupational exposure mode is by dermal absorption following contact with contaminated surfaces, whereas inhalation and ingestion are minor pathways (304). Few epidemiological studies have been available to the IARC to evaluate its association with the risk of bladder cancer.

In vivo studies have indicated an increased incidence of HCC, lung and mammary gland adenocarcinoma $(305,306)$. MOCA is an IARC Group 1 agent, its genotoxicity is clearly documented (135). Its toxicological MOA is similar to that of $o$-toluidine, MOCA interacts with DNA and hemoglobin to form adducts, SCE and MN in urothelial cells and lymphocytes of exposed workers (135). MOCA concentrations in blood and urine are monitored in MOCA-exposed workers.

4-Aminobiphenyl (4-ABP). 4-ABP (CAS no. 92-67-1) was formerly used in rubber and dye industry. It is classified as a Group 1 carcinogen to humans (135). It is now used as a carcinogenic agent in mutagenicity studies and cancer research $(135,302,303)$. Major non-occupational sources of exposure to 4-ABP are tobacco smoke and hair dyes (307).

Historically, occupational exposure was mainly during its production and use as a rubber antioxidant and dye intermediate, however, no exposure measurements are available for these situations (295). Occupational exposure can occur during work 
with 4-ABP-contaminated products, or during the exposure to benzidine (Bzd) and Bzd-based dyes (295). Epidemiological surveys in US chemical plants indicate a high incidence of bladder cancer among workers exposed to 4-ABP $(308,309)$. Oral 4-ABP administration has been reported to result in an increased incidence of angiosarcoma in mice of both genders; bladder carcinoma and HCC in male and female mice, respectively $(310,311)$; and bladder carcinoma in dogs of both genders (312,313). Subcutaneous (314) or intraperitoneal injection $(315,316)$ have been demonstrated to increase HCC incidence in male mice.

4-ABP is metabolized by hepatic CYP1A2 to yield $N$-hydroxy ABP, a direct-acting mutagen capable of inducing tumors at the site of application $(317,318)$. Animal studies have demonstrated that administration to dogs results in formation of $N$-(deoxyguanonsin-8-yl)-4-ABP (dG-C8-ABP) as the major DNA adduct ( $70 \%$ of total adducts) in hepatocytes and bladder cells $(319,320)$. In BALB/c mice, a linear association has been described between dG-C8-ABP levels in liver DNA and liver tumor incidence (312). In human liver tissue, higher 4-ABP-DNA levels were observed in HCC cases compared with controls (321-323). Despite observation of a dose-associated increase in 4-ABP DNA, tested using number of cigarettes smoked/day, and an association with mutant p53 protein expression in bladder cancers (324), there are currently no reports of p53 or other specific gene mutations that result from exposure to polycyclic aromatic hydrocarbons or 4-ABP in HCC (307).

Carcinogenicity of 4-ABP in humans operates by a genotoxic MOA that involves formation of DNA adducts, and induction of mutagenic and clastogenic effects. Metabolic activation to DNA-reactive intermediates occurs by multiple pathways, including $\mathrm{N}$-oxidation in liver, $\mathrm{O}$-acetylation in bladder, and peroxidative activation in the mammary glands and other organs (135). Ac4ABP is the predominant 4-ABP metabolite detected in urine of occupationally exposed subjects.

Bzd and dyes metabolized to Bzd. Bzd (CAS no. 92-87-5) and dyes metabolized to Bzd, including Direct Black 38 (CAS no. 1937-37-7), Direct Blue 6 (CAS no. 2602-46-2), and Direct Brown 95 (CAS no. 16071-86-6) are Group 1 carcinogens (135).

Bzd has been used as reagent base for dye production, which are used primarily to color textiles, leather, and paper products and also in the petroleum, rubber, plastics, wood, soap, fur, and hair-dye industries.

Direct Black 38, Blue 6 and Brown 95 were used for textiles and leather products. They were also used in aqueous printing inks, in hair dyes and as biological stains (Black 38 and Blue 6); in plastic (Black 38 and Brown 95); in paper (Blue 6 and Brown 95); and in wood stains and wood floor (Black 38) (135).

In the 1970s, USA manufacturers replaced them with other dyes (325). In 2002, the EU Directive (76/769/EEC) banned azo-dyes in compounds that may come into contact with the oral cavity or human skin (such as clothing and gloves) (326).

Workers were usually exposed to Bzd-based dyes during their production and use. The primary routes of potential exposure include inhalation, accidental ingestion, and dermal absorption.
The potential for exposure has declined since the late 1970 s, when they were replaced with other dye types. Since 1980, use of Bzd-containing mixtures at concentrations $\geq 0.1 \%$ is permitted exclusively in closed systems and workers are required to observe special precautions to reduce exposure. Strict transport procedures have also been adopted (327).

The general population can be exposed to Bzd through contact with articles containing its based dyes, such as leather (326), clothes and toys (328). Traces of Bzd were reported in food colorants, such as tartrazine and sunset yellow FCF (329).

Epidemiological surveys have not clarified the association between Bzd exposure and human cancer. In vivo studies on male and female rats demonstrated that following 13 weeks oral administration of Direct Black 38, Blue 6, and Brown 95, there was a significant increase in HCC in males and of neoplastic liver nodules in both genders $(330,331)$.

Monoacetylbenzidine (MoAcBzd) is the predominant Bzd metabolite in the urine of occupationally exposed subjects.

Aflatoxins. Aflatoxin is a mycotoxin produced by fungi of the Aspergillus species, which grow rapidly on foods, such as corn and peanuts, stored in warm, damp conditions. Optimum conditions for mycotoxin production are a temperature range of $25-32^{\circ} \mathrm{C}$, a moisture content range of $12-16 \%$, and a relative humidity of $85 \%(332,333)$.

Aflatoxins (AFB1, aflatoxin B2, aflatoxin G1, and aflatoxin G2) are known to be carcinogenic to humans and animals, AFB1 is considered a more potent hepatotoxic and hepatocarcinogenic agent $(334,335)$. The IARC has classified 'naturally occurring aflatoxin' as a Group 1 human carcinogen (135). Two forms of aflatoxin poisoning are recognized, acute severe intoxication, which results in direct liver damage followed by illness and mortality, and chronic symptomatic exposure (332).

AFB1 is genotoxicand apotenthepatocarcinogen(336-338). It is bioactivated by cytochrome P450 (CYP), a group of enzymes found abundantly in the liver that are associated with the bioactivation and metabolism of multiple xenobiotics and endogenous compounds (339). In particular, CYP enzymes bioactivate AFB1 to an unstable metabolite (AFB1-8, 9-epoxide) that can react with cellular macromolecules, such as DNA and proteins to form covalent adducts causing genotoxicity and cytotoxicity (337,340-342). AFB1 is converted to AFB1-8, 9-exo-epoxide, which in turn is converted to the 8,9-dihydroxy-8-(N7)guanyl-9-hydroxy AFB1 adduct (334). To date, all animal models that have been exposed to AFB1 have developed HCC (334). Numerous studies have demonstrated a dose-response association between AFB1 adduct levels, HCC risk, and years of AFB1 exposure $(34,35,343)$. These data are consistent with reports of an association between airway AFB1 exposure and serum AFB1 adducts, which may correlate with an increased risk of AFB1-associated HCC $(335,344)$.

Whereas a strong association between dietary AFB1 exposure and HCC risk has been established (334), an association to AFB1 airway exposure has been hypothesized. Of the 550,000-600,000 new HCC cases worldwide each year, 25,200-155,000 may be attributable to aflatoxin exposure (335). Approximately $40 \%$ of those affected live in 
sub-Saharan Africa (332). The latency period for the development of AFB1-induced HCC remains unknown (334).

AFB1-induced adducts may be fixed as mutations consequent to an HBV-associated increase in hepatocyte turnover. An arginine to serine ( $\mathrm{G}$ to $\mathrm{T}$ ) mutation at codon 249 of the p53 tumor suppressor gene (R249S; Ser249 mutation) is specific for exposure to aflatoxin and is detected in as many as $64 \%$ of $\mathrm{HCC}$ patients $(135,38-40,345)$. The mutation accounts for $90 \%$ of p53 mutations in AFB1-associated HCC cases (346), suggesting that it confers a selective advantage during hepatocarcinogenesis. In addition, Ser249 is observed in tumor tissue from up to $75 \%$ of Chinese patients (39) and $56 \%$ of Mozambican Shangaans with HCC (38). The mutation is also detected in $44 \%$ of HCC patients who have no evidence of cirrhosis, supporting a direct, in addition to an indirect, hepatocarcinogenic effect of AFB1 (40). The simultaneous presence of the Ser249 mutation and chronic HBV infection is associated to an odds ratio of developing HCC of 399 (95\% CI, 486-3270) (41). AFB1 and chronic HBV infection co-exist in the countries with the highest HCC incidence, raising the possibility of a synergistic hepatocarcinogenic interaction (41).

Workers exposed to aflatoxins by inhalation, particularly in the form of airborne dust, are prone to ingestion, transmucosal absorption, and inhalation of AFB1 released during storage, loading, handling, or milling of contaminated materials, such as grain, waste, feed, corn and other substances (340,42-46). Dermal absorption is particularly severe in workplaces where short clothes are allowed and large skin areas are exposed to particulate matter deposition $(47,48)$.

A recent study conducted in a paper mill and sugar factory demonstrated that AFB1 airway exposure may result in serum AFB1 adducts and HCC risk (50). Poultry production and rice mill workers who are in direct contact with grain dust are often exposed to AFB1 $(46,49-50,338,340)$. Other types of AFB1 exposure include, workers employed in waste management or swine production (338), agri-food industry (347) and wheat handling (348). Textile workers may also be occupationally exposed during pre-spinning, spinning, and weaving (349). Textile workers account for a large proportion of the workforce in Egypt (349), where a significant correlation has been observed between tumor markers and urinary AFB1 in workers and controls who tested positive for Aspergillus niger (349).

\section{Risk prevention in the workplace}

Workplace risk prevention and safety rely predominantly on eliminating the risk itself known as primary prevention. However, where this is not technically feasible, technical, organizational, and procedural measures have to be enacted to reduce risk of exposure to a minimum (350).

When chemical agents are involved, primary prevention entails replacing a toxic agent with a non-toxic one. However, certain mutagenic/carcinogenic agents can be produced in synthetic processes as intermediates or as waste products (351).

When risk assessment determines the existence of a healthy risk, adequate risk control systems must be implemented. These systems are divided into general and personal protection devices (PPD). The former includes adoption of technical and procedural measures, for instance the reduction of environmental pollutants, whereas PPD largely consist of devices worn by workers (such as masks and gloves), preventing direct contact with vapors, fumes and/or potentially contaminated material.

In workplaces where risks are documented, safety procedures must be instituted in accordance with national guidelines. In case of flaws or deficiencies in such guidelines, those in charge of workplace safety are required to refer to the guidelines of internationally recognized organizations, such as the American Conference of Industrial Hygienists or National Institute for Occupational Safety and Health.

The employer and occupational physician have key roles in preventing occupational risk and diseases. The occupational physician, in addition to conducting biological monitoring and health surveillance (known as secondary prevention), is responsible for promoting workplace health (350-356).

With regards to specific HCC prevention, all exposed workers should have HBV vaccination. In addition, campaigns against smoking and drinking alcohol should be organized, providing explicit warning that these factors may be important in liver cancer development (82).

\section{Conclusion}

Hepatic disorders are common in conditions worldwide. They are important in occupational medicine as the majority of chemicals are metabolized in the liver, and toxic metabolites generated during metabolism are the predominant cause of liver damage. However, numerous liver diseases are difficult to diagnose due to non-specific clinical manifestations. Furthermore, given the high incidence of liver diseases like alcoholic or viral hepatitis, it is difficult to demonstrate an occupational cause. Concomitant conditions, such as viral hepatitis and alcohol or drug abuse, may mask liver disorders resulting from occupational hepatotoxic agents (357).

Epidemiological studies have demonstrated a causal association between tobacco exposure, alcohol consumption, HBV and HCV infection, and HCC, and the occupational origin of certain types of human cancer is well established. The identification of the environmental causes of human cancers has been a long and difficult process. The role of specific dietary components and the interaction of different risk factors in the etiology of human cancer remains to be determined. Despite the progress achieved in understanding the cancer process, and the impact of this knowledge on treatment, primary prevention remains the most effective approach to reduce cancer mortality in developed and developing countries (358).

\section{References}

1. International agency for research on cancer (IARC): Review of Human Carcinogens. IARC Monogr Vol 100. Lyon, France. 2012.

2. Ferlay J, Shin HR, Bray F, Forman D, Mathers C and Parkin DM: Estimates of worldwide burden of cancer in 2008: GLOBOCAN 2008. Int J Cancer 127: 2893-2917, 2010.

3. Chen CJ, Yu MW and Liaw YF: Epidemiological characteristics and risk factors of hepatocellular carcinoma. J Gastroenterol Hepatol 12 (Suppl): S294-S308, 1997. 
4. Montesano R, Hainaut P and Wild CP: Hepatocellular carcinoma: From gene to public health. J Natl Cancer Inst 89: 1844-1851, 1997.

5. Yu MC, Yuan JM, Govindarajan S and Ross RK: Epidemiology of hepatocellular carcinoma. Can J Gastroenterol 14: 703-709, 2000.

6. Stuver SO: Towards global control of liver cancer? Semin Cancer Biol 8: 299-306, 1998.

7. Wogan GN: Impacts of chemicals on liver cancer risk. Semin Cancer Biol 10: 201-210, 2000.

8. International Agency for Research on Cancer (IARC): Hormonal contraception and post-menopausal hormonal therapy. IARC Monogr Vol 72. Lyon, France, 1999.

9. Sherman M: Vinyl chloride and the liver. J Hepatol 51: 1074-1081, 2009.

10. Wong O, Morgan RW, Kheifets L, Larson SR and Whorton MD: Mortality among members of a heavy construction equipment operators union with potential exposure to diesel exhaust emissions. Br J Ind Med 42: 435-448, 1985.

11. Gustavsson P, Gustavsson A and Hogstedt C: Excess mortality among Swedish chimney sweeps. Br J Ind Med 44: 738-743, 1987.

12. Rinsky RA, Ott G, Ward E, Greenberg H, Halperin W and Leet T: Study of mortality among chemical workers in the Kanawha Valley of West Virginia. Am J Ind Med 13: 429-438, 1988.

13. Rafnsson V and Gunnarsdottir H: Mortality among Icelandic seamen. Int J Epidemiol 23: 730-736, 1994.

14. Steenland K and Palu S: Cohort mortality study of 57,000 painters and other union members: A 15 year update. Occup Environ Med 56: 315-321, 1999.

15. Chen R and Seaton A: A meta-analysis of mortality among workers exposed to organic solvents. Occup Med (Lond) 46: 337-344, 1996.

16. Gibbs GW, Amsel J and Soden K: A cohort mortality study of cellulose triacetate-fiber workers exposed to methylene chloride. J Occup Environ Med 38: 693-697, 1996.

17. Chow WH, McLaughlin JK, Zheng W, Blot WJ and Gao YT: Occupational risks for primary liver cancer in Shanghai, China. Am J Ind Med 24: 93-100, 1993.

18. Suarez L, Weiss NS and Martin J: Primary liver cancer death and occupation in Texas. Am J Ind Med 15: 167-175, 1989.

19. Heinemann K, Willich SN, Heinemann LA, DoMinh T, Möhner M and Heuchert GE: Occupational exposure and liver cancer in women: Results of the multicentre international liver tumour study (MILTS). Occup Med (Lond) 50: 422-429, 2000

20. Chang CK, Astrakianakis G, Thomas DB, Seixas NS, Ray RM, Gao DL, Wernli KJ, Fitzgibbons ED, Vaughan TL and Checkoway H: Occupational exposures and risks of liver cancer among Shanghai female textile workers-a case-cohort study. Int J Epidemiol 35: 361-369, 2006.

21. Oh JK and Weiderpass E: Infection and cancer: Global distribution and burden of diseases. Ann Glob Health 80: 384-392, 2014.

22. Bouvard V, Baan R, StraifK, Grosse Y, Secretan B,El Ghissassi F, Benbrahim-Tallaa L, Guha N, Freeman C, Galichet L, et al: A review of human carcinogens-Part B: Biological agents. Lancet Oncol 10: 321-322, 2009

23. International Agency for Research on Cancer (IARC): Monographs on the evaluation of carcinogenic risks to humans. A review of carcinogen-part B: Biological Agents. Lyon, France, 2011.

24. McElvenny D, Agius R, Cherrie J and de Vocht F: 0214 Cancer mortality in the British Rubber industry- a 45 year follow-up. Occup Environ Med 71: A88, 2014

25. Bolognesi $\mathrm{C}$ and Moretto $\mathrm{A}$ : Genotoxic risk in rubber manufacturing industry: A systematic review. Toxicol Lett 230: 345-355, 2014.

26. de Vocht F, Burstyn I, Straif K, Vermeulen R, Jakobsson K, Nichols L, Peplonska B, Taeger D and Kromhout H: Occupational exposure to NDMA and NMor in the European rubber industry. J Environ Monit 9: 253-259, 2007.

27. Jönsson LS, Lindh CH, Bergendorf U, Axmon A, Littorin M and Jönsson BA: N-nitrosamines in the southern Swedish rubber industries-exposure, health effects and immunologic markers. Scand J Work Environ Health 35: 203-211, 2009.

28. Iavicoli I and Carelli G: Evaluation of occupational exposure to $\mathrm{N}$-nitrosamines in a rubber-manufacturing industry. J Occup Environ Med 48: 195-198, 2006.
29. Baccarelli A, Mocarelli P, Patterson DG Jr, Bonzini M, Pesatori AC, Caporaso N and Landi MT: Immunologic effects of dioxin: New results from Seveso and comparison with other studies. Environ Health Perspect 110: 1169-1173, 2002.

30. National Institute of Occupational Safety and Health (NIOSH). National occupational exposure survey. Department of Health and Human Services, Cincinnati, OH, 2015. http://www.cdc. gov/niosh.

31. Tijet N, Boutros PC, Moffat ID, Okey AB, Tuomisto J and Pohjanvirta R: Aryl hydrocarbon receptor regulates distinct dioxin-dependent and dioxin-independent gene batteries. Mol Pharmacol 69: 140-153, 2006.

32. Walker NJ, Crockett PW, Nyska A, Brix AE, Jokinen MP, Sells DM, Hailey JR, Easterling M, Haseman JK, Yin M, et al: Dose-additive carcinogenicity of a defined mixture of 'dioxin-like compounds'. Environ Health Perspect 113: 43-48, 2005.

33. Manne V, Sassi K, Allen R and Saab S: Hepatitis C and work impairment: A review of current literature. J Clin Gastroenterol 48: 595-599, 2014

34. Lin ZH, Chen JC, Wang YS, Huang TJ, Wang J and Long XD: DNA repair gene XRCC4 codon 247 polymorphism modified diffusely infiltrating astrocytoma risk and prognosis. Int J Mol Sci 15: 250-260, 2013.

35. Long XD, Yao JG, Zeng Z, Ma Y, Huang XY, Wei ZH, Liu M, Zhang JJ, Xue F, Zhai B and Xia Q: Polymorphisms in the coding region of $\mathrm{X}$-ray repair complementing group 4 and aflatoxin B1-related hepatocellular carcinoma. Hepatology 58: $171-181,2013$

36. Hu T, Du Q, Ren F, Liang S, Lin D, Li J and Chen Y: Spatial analysis of the home addresses of hospital patients with hepatitis B infection or hepatoma in Shenzhen, China from 2010 to 2012. Int J Environ Res Public Health 11: 3143-3155, 2014.

37. Liu Y, Chang CC, Marsh GM and Wu F: Population attributable risk of aflatoxin-related liver cancer: Systematic review and meta-analysis. Eur J Cancer 48: 2125-2136, 2012.

38. Bressac B, Kew M, Wands J and Ozturk M: Selective G to T mutations of 553 genein hepatocellular carcinoma from southern Africa. Nature 350: 429-431, 1991.

39. Hsu IC, Metcalf RA, Sun T, Welsh JA, Wang NJ and Harris CC: Mutational hotspot in the p53 gene in human hepatocellular carcinomas. Nature 350: 427-428, 1991.

40. Villar S, Ortiz-Cuaran S, Abedi-Ardekani B, Gouas D, Nogueira da Costa A, Plymoth A, Khuhaprema T, Kalalak A, Sangrajrang S, Friesen MD, et al: Aflatoxin-induced TP53 R249S mutation in hepatocellular carcinoma in Thailand: Association with tumors developing in the absence of liver cirrhosis. PLoS One 7: e37707, 2012.

41. Kirk GD, Lesi OA, Mendy M, Szymañska K, Whittle H, Goedert JJ, Hainaut P and Montesano R: 249(ser) TP53 mutation in plasma DNA, hepatitis B viral infection, and risk of hepatocellular carcinoma. Oncogene 24: 5858-5867, 2005.

42. Sorenson WG, Simpson JP, Peach MJ III, Thedell TD and Olenchock SA: Aflatoxinin respirable corn dust particles. J Toxicol Environ Health 7: 669-672, 1981.

43. Jargot D and Melin S: Characterization and validation of sampling and analutical methods for mycotoxins in workplace air. Environ Sci Process Impacts 15: 633-644, 2013

44. Viegas S, Veiga L, Malta-Vacas J, Sabino R, Figueredo P, Almeida A, Viegas $C$ and Carolino E: Occupational exposure to aflatoxin $\left(\mathrm{AFB}_{1}\right)$ in poultry production. $\mathbf{J}$ Toxicol Environ Health A 75: 1330-1340, 2012.

45. Burg WA, Shotwell OL and Saltzman BE: Measurements of airborne aflatoxins during the handling of contaminated corn. Am Ind Hyg Assoc J 42: 1-11, 1981.

46. Viegas S, Faísca VM, Dias H, Clérigo A, Carolino E and Viegas C: Occupational exposure to poultry dust and effects on the respiratory system in workers. J Toxicol Environ Health A 76: 230-239, 2013.

47. Degen GH: The challenge to assess workplace related risks from mycotoxin exposure. Mycotoxin Res 24: i-ii, 2008.

48. Mayer S, Engelhart S, Kolk A and Blome H: The significance of mycotoxins in the framework of assessing workplace related risks. Mycotoxin Res 24: 151-164, 2008.

49. Autrup JL, Schmidt J and Autrup H: Exposure to aflatoxin B1 in animal-feed production plant workers. Environ Health Perspect 99: 195-197, 1993.

50. Ghosh SK, Desai MR, Pandya GL and Venkaiah K: Airborne aflatoxin in the grain processing industries in India. Am Ind Hyg Assoc J 58: 583-586, 1997. 
51. Desai MR and Ghosh S: Occupational exposure to airborne fungi among rice mill workers with special reference to aflatoxin producing A. Flavus strains. Ann Agric Environ Med 10: 159-162, 2003.

52. Dow Chemical Company (DCC): Product Safety Assessment: Vinyl Chloride Monomer, 2007. http://www.dow.com.productsafety/finder/vcm.htm. Accessed January 7, 2016.

53. Levy BS, Wegman DH, Baron SL and Sokas RK (eds): Occupational and environmental health: Recognizing and preventing disease and injury. 6th edition Oxford University Press, Inc. New York, NY, 2011.

54. Lopez V, Chamoux A, Tempier M, Thiel H, Ughetto S, Trousselard M, Naughton G and Dutheil F: The long-term effects of occupational exposure to vinyl chloride monomer on microcirculation: A cross-sectional study 15 years after retirement. BMJ Open 3: pii.e002785, 2013.

55. Lewis R, Rempala G, Dell LD and Mundt KA: Vinyl chloride and liver and brain cancer at a polymer production plant in Louisville, Kentucky. J Occup Environ Med 45: 533-537, 2003.

56. Trivers GE, Cawley HL, DeBenedetti VM, Hollstein M, Marion MJ, Bennett WP, Hoover ML, Prives CC, Tamburro CC and Harris CC: Anti-p53 antibodies in sera of workers occupationally exposed to vinyl chloride. J Natl Cancer Inst 87: 1400-1407, 1995.

57. Mastrangelo G, Fedeli U, Fadda E, Valentini F, Agnesi R, Magarotto G, Marchì T, Buda A, Pinzani M and Martines D: Increased risk of hepatocellular carcinoma and liver cirrhosis in vinyl chloride workers: Synergistic effect of occupational exposure with alcohol intake. Environ Health Perspect 112: 1188-1192, 2004.

58. Weihrauch M, Benick M, Lehner G, Wittekind M, Bader M, Wrbitzk R and Tannapfel A: High prevalence of K-ras-2 mutations in hepa-tocellular carcinomas in workers exposed to vinyl chloride. Int Arch Occup Environ Health 74: 405-410, 2001.

59. Ward E, Boffetta P, Andersen A, Colin D, Comba P, Deddens JA, De Santis M, Engholm G, Hagmar L, Langard S, et al: Update of the follow-up of mortality and cancer incidence among European workers employed in the vinyl chloride industry. Epidemiology 12: 710-718, 2001.

60. Wong RH, Chen PC, Du CL, Wang JD and Cheng TJ: An increased standardised mortality ratio for liver cancer among polyvinyl chloride workers in Taiwan. Occup Environ Med 59: 405-409, 2002.

61. Wong RH, Chen PC, Wang JD, Du CL and Cheng TJ: Interaction of vinyl chloride monomer exposure and hepatitis B viral infection on liver cancer. J Occup Environ Med 45: 379-383, 2003.

62. Gennaro V, Ceppi M and Montanaro F: Reanalysis of mortality in a petrochemical plant producing vinyl chloride and polyvinyl chloride. Epidemiol Prev 27: 221-225, 2003 (In Italian).

63. Scott CS and Chiu WA: Trichloroethylene cancer epidemiology: A consideration of select issues. Environ Health Perspect 114: 1471-1478, 2006.

64. Gennaro V, Ceppi M, Crosignani P and Montanaro F: Reanalysis of updated mortality among vinyl and polyvinyl chloride workers: Confirmation of historical evidence and new findings. BMC Public Health 8: 21, 2008.

65. Pirastu R, Baccini M, Biggeri A and Comba P: Epidemiologic study of workers exposed to vinyl chloride in Porto Marghera: Mortality update. Epidemiol Prev 27: 161-172, 2003 (In Italian).

66. Campos-Outcalt D: Tricloroethylene: Environmental and occupational exposure. Am Fam Physician 46: 495-500, 1992.

67. International Agency for Research on Cancer (IARC): Some chemicals used in plastics and elastomers. IARC Monogr Vol 39. Lyon, France, 1986.

68. Porru S, Placidi D, Carta A, Gelatti U, Ribero ML, Tagger A, Boffetta P and Donato F: Primary liver cancer and occupation in men: A case-control study in a high-incidence area in Northern Italy. Int J Cancer 94: 878-883, 2001.

69. Zhou YC and Waxman DJ: Activation of peroxisome proliferator-activated receptors by chlorinated hydrocarbons and endogenous steroids. Environ Health Perspect 106 (Suppl 4): S983-S988, 1998

70. Lynge E and Thygesen L: Primary liver cancer among women in laundry and dry-cleaning work in Denmark. Scand J Work Environ Health 16: 108-112, 1990.

71. Sano Y, Nakashima H, Yoshioka N, Etho N, Nomiyama T, Nishiwaki Y, Takebayashi T and Oame K: Trichloroethylene liver toxicity in mouse and rat: Microarray analysis reveals species differences in gene expression. Arch Toxicol 83: 835-849, 2009.
72. Pogribny IP, Rusyn I and Beland FA: Epigenetic aspects of genotoxic and non-genotoxic hepatocarcinogenesis: Studies in rodents. Environ Mol Mutagen 49: 9-15, 2008.

73. Chiu WA and Ginsberg GL: Development and evaluation of a harmonized physiologically based pharmacokinetic (PBPK) model for perchloroethylene toxicokinetics in mice, rats, and humans. Toxicol Appl Pharmacol 253: 203-234, 2011.

74. Budke B, Chan YL, Bishop DK and Connell PP: Real-time solution measurement of RAD51- and RecA-mediated strand assimilation without background annealing. Nucleic Acids Res 41: e130, 2013

75. Jiang Y, Chen J, Tong J and Chen T: Trichloroethylene-induced gene expression and DNA methylation changes in B6C3F1 mouse liver. PLoS One 9: e116179, 2014.

76. Environmental Protection Agency (EPA): Integrated Risk Information System (IRIS) on Tetrachloroethylene. National Center for Environmental Assessment. Office of Research and Development, Washington, D.C., 2012.

77. Centers for Disease Control and Prevention (CDC): Workplace safety and health topics. Pesticide illness and injury surveillance 2013. http://www.cdc.gov/niosh/topics/pesticides. Accessed January 7, 2016.

78. Costa C, Rapisarda V, Catania S, Di Nola C, Ledda C and Fenga C: Cytokine patterns in greenhouse workers occupationally exposed to $\alpha$-cypermethrin: An observational study. Environ Toxicol Pharmacol 36: 796-800, 2013.

79. Freire C, Koifman RJ and Koifman S: Hematological and hepatic alterations in Brazilian population heavily exposed to organochlorine pesticides. J Toxicol Environ Health A 78: 534-548, 2015

80. Cordier S, Le TB, Verger P, Bard D, Le CD, Larouze B, Dazza MC, Hoang TQ and Abenhaim L: Viral infections and chemical exposures as risk factors for hepatocellular carcinoma in Vietnam. Int J Cancer 55: 196-201, 1993.

81. Anwar WA, Khaled HM, Amra HA, El-Nezami H and Loffredo CA: Changing pattern of hepatocellular carcinoma (HCC) and its risk factors in Egypt: Possibilities for prevention. Mutat Res 659: 176-184, 2008.

82. Soliman AS, Hung CW, Tsodikov A, Seifeldin IA, Ramadan M, Al-Gamal D, Schiefelbein EL, Thummalapally P, Dey S and Ismail K: Epidemiologic risk factors of hepatocellular carcinoma in a rural region of Egypt. Hepatol Int 4: 681-690, 2010.

83. Rossi L, Ravera M, Repetti G and Santi L: Long-term administration of DDT or phenobarbital-Na in Wistar rats. Int J Cancer 19: 179-185, 1977.

84. Tomatis L, Turusov V, Day N and Charles RT: The effect of long-term exposure to DDT on CF-1 MICE. Int J Cancer 10: 489-506, 1972.

85. Turusov VS, Day NE, Tomatis L, Gati E and Charles RT: Tumors in CF-1 mice exposed for six consecutive generations to DDT. J Natl Cancer Inst 51: 983-997, 1973.

86. Yang X, Wang S, Bian Y, Chen F, Yu G, Gu C and Jiang X: Dicofol application resulted in high DDTs residue in cotton fields from northern Jiangsu province, China. J Hazard Mater 150: 92-98, 2008

87. van den Berg H: Global status of DDT and its alternatives for use in vector control to prevent disease. Cien Saude Colet 16: 575-590, 2011.

88. Rogan WJ and Chen A: Health risks and benefits of bis(4-chlorophenyl)-1,1,1-trichloroethane (DDT). Lancet 366: 763-773, 2005

89. Smith AG: DDT and its analogs. In: Handbook of Pesticide Toxicology. Krieger R (ed). 2nd edition. Academic Press, San Diego, CA, pp1305-1355, 2001.

90. World Health Organization (WHO): DDT and its derivatives. Environmental health criteria 9. WHO, Geneva, Switzerland, 1979.

91. Figà-Talamanca I, Mearelli I and Valente P: Mortality in a cohort of pesticide applicators in an urban setting. Int J Epidemiol 22: 674-676, 1993

92. McGlynn KA, Abnet CC, Zhang M, Sun XD, Fan JH, O'Brien TR, Wei WQ, Ortiz-Conde BA, Dawsey SM, Weber JP, et al: Serum concentrations of 1,1,1-trichloro-2,2-bis(p-chlorophenyl)ethane (DDT) and 1,1-dichloro-2,2-bis(p-chlorophenyl)ethylene (DDE) and risk of primary liver cancer. J Natl Cancer Inst 98: 1005-1010, 2006.

93. Zhao B, Shen H, Liu F, Liu S, Niu J, Guo F and Sun X: Exposure to organochlorine pesticides is independent risk factor of hepatocellular carcinoma: A case-control study. J Expo Sci Environ Epidemiol 21: 601-608, 2011. 
94. Cocco P, Kazerouni N and Zahm SH: Cancer mortality and environmental exposure to DDE in the United States. Environ Health Perspect 108: 1-4, 2000.

95. International Agency for Research on Cancer (IARC): Some N-nitroso compounds. IARC Monogr Vol 17. Lyon, France, 1978.

96. World Health Organization (WHO): Preventing disease through healthy environments. Exposure to arsenic: A major public health concern. WHO, Geneva, Switzerland, 2010.

97. Agency for Toxic Substances and Disease Registry (ATSDR): Case Studies in environmental medicine: Arsenic toxicity. US Public Health Service, US Department of Health and Human Services, Atlanta, GA, 2011

98. Amadori S, Fenaux P, Ludwig H, O'Dwyer M and Sanz M: Use of arsenic trioxide in haematological malignancies: Insight into the clinical development of a novel agent. Curr Med Res Opin 21: 403-411, 2005.

99. Chen CJ, Chen CW, Wu MM and Kuo TL: Cancer potential in liver, lung, bladder and kidney due to ingested inorganic arsenic in drinking water. Br J Cancer 66: 888-892, 1992.

100. Marshall G, Ferreccio C, Yuan Y, Bates MN, Steinmaus C, Selvin S, Liaw J and Smith AH: Fifty-year study of lung and bladder cancer mortality in Chile related to arsenic in drinking water. J Natl Cancer Inst 99: 920-928, 2007.

101. Tapio S and Grosche B: Arsenic in the aetiology of cancer. Mutat Res 612: 215-246, 2006.

102.Xi S, Zheng Q, Zhang Q and Sun G: Metabolic profile and assessment of occupational arsenic exposure in copper- and steel-smelting workers in China. Int Arch Occup Environ Health 84: 347-353, 2011.

103. Gregus Z and Németi B: Purine nucleoside phosphorylase as a cytosolic arsenate reductase. Toxicol Sci 70: 13-19, 2002.

104. Liu J and Waalkes MP: Liver is a target of arsenic carcinogenesis. Toxicol Sci 105: 24-32, 2008.

105.Liu J, Kadiiska MB, Liu Y, Lu T, Qu W and Waalkes MP: Stress-related gene expression in mice treated with inorganic arsenicals. Toxicol Sci 61: 314-320, 2001.

106. Thomas DJ: Molecular processes in cellular arsenic metabolism. Toxicol Appl Pharmacol 222: 365-373, 2007.

107.International Agency for Research on Cancer (IARC): Some Metals and Metallic Compounds. IARC Monogr Vol 23. Lyon, France, 1980.

108. International Agency for Research on Cancer (IARC): Some drinking-water disinfectants and contaminants, including arsenic. IARC Monogr Vol 84. Lyon, France, 2004

109. International Agency for Research on Cancer (IARC): Arsenic, Metals, Fibres and Dusts. IARC Monogr Vol 100C. Lyon, France, 2012.

110. Mazumder DN: Effect of chronic intake of arsenic-contaminated water on liver. Toxicol Appl Pharmacol 206: 169-175, 2005.

111. Pershagen G: The carcinogenicity of arsenic. Environ Health Perspect 40: 93-100, 1981 .

112. Reichard JF, Schnekenburger $M$ and Puga A: Long term low-dose arsenic exposure induces loss of DNA methylation. Biochem Biophys Res Commun 352: 188-192, 2007.

113. Tokar EJ, Benbrahim-Tallaa L, Ward JM, Lunn R, Sams RL II and Waalkes MP: Cancer in experimental animals exposed to arsenic and arsenic compounds. Crit Rev Toxicol 40: 912-927, 2010.

114. Wanibuchi H, Salim EI, Kinoshita A, Shen J, Wei M, Morimura K, Yoshida K, Kuroda K, Endo G and Fukushima S Understanding arsenic carcinogenicity by the use of animal models. Toxicol Appl Pharmacol 198: 366-376, 2004.

115. Waalkes MP, Liu J and Diwan BA: Transplacental arsenic carcinogenesis in mice. Toxicol Appl Pharmacol 222: 271-280, 2007.

116. Qu W, Bortner CD, Sakurai T, Hobson MJ and Waalkes MP Acquisition of apoptotic resistance in arsenic-induced malignant transformation: Role of the JNK signal transduction pathway. Carcinogenesis 23: 151-159, 2002.

117. Waalkes MP, Keefer LK and Diwan BA: Induction of proliferative lesions of the uterus, testes, and liver in swiss mice given repeated injections of sodium arsenate: Possible estrogenic mode of action. Toxicol Appl Pharmacol 166: 24-35, 2000

118. Rossman TG: Mechanism of arsenic carcinogenesis: An integrated approach. Mutat Res 533: 37-65, 2003.

119. Waalkes MP, Ward JM and Diwan BA: Induction of tumors of the liver, lung, ovary and adrenal in adult mice after brief maternal gestational exposure to inorganic arsenic: Promotional effects of postnatal phorbol ester exposure on hepatic and pulmonary, but not dermal cancers. Carcinogenesis 25: 133-141, 2004.
120. National Toxicology Program (NTP): Report on Carcinogens. Carcinogen profiles: Cadmium and cadmium compounds. 11th edition. US Department of Health and Human Services, Public Health Service, National Toxicology Program, Research Triangle Park, NC, 2004.

121. Huff J, Cirvello J, Haseman J and Bucher J: Chemicals associated with site-specific neoplasia in 1394 long-term carcinogenesis experiments in laboratory rodents. Environ Health Perspect 93: 247-270, 1991

122. Agency for Toxic Substances and Disease Registry (ATSDR) Toxicological Profile for Cadmium. US Public Health Service, US Department of Health and Human Services, Atlanta, GA. 1999.

123. Satarug S, Garrett SH, Sens MA and Sens DA: Cadmium, environmental exposure, and health outcomes. Environ Health Perspect 118: 182-190, 2010

124. Satarug S: Long-term exposure to cadmium in food and cigarette smoke, liver effects and hepatocellular carcinoma. Curr Drug Metab 13: 257-271, 2012

125. International Agency for Research on Cancer (IARC) Beryllium, cadmium, mercury and exposures in the glass manufacturing industry. IARC Monogr Vol 58. Lyon, France, 1993.

126. Rani A, Kumar A, Lal A and Pant M: Cellular mechanisms of cadmium-induced toxicity: A review. Int J Environ Health Res 24: 378-399, 2014.

127. Campbell TC, Chen JS, Liu CB, Li JY and Parpia B: Nonassociation of aflatoxin with primary liver cancer in a cross-sectional ecological survey in the People's Republic of China. Cancer Res 50: 6882-6893, 1990.

128. Waalkes MP and Rehm S: Chronic toxic and carcinogenic effects of cadmium chloride in male DBA/2NCr and $\mathrm{NFS} / \mathrm{NCr}$ mice: Strain-dependent association with tumors of the hematopoietic system, injection site, liver, and lung. Fundam Appl Toxicol 23: 21-31, 1994

129. Wade GG, Mandel R and Ryser HJ: Marked synergism of dymethylnitrosamine carcinogenesis in rats exposed to cadmium. Cancer Res 47: 6606-6613, 1987.

130. Franco R, Schoneveld O, Georgakilas AG and Panayiotidis MI: Oxidative stress, DNA methylation and carcinogenesis. Cancer Lett 266: 6-11, 2008

131. Takiguchi M, Achanzar WE, Qu W, Li G and Waalkes MP: Effects of cadmium on DNA-(Cytosine-5) methyltransferase activity and DNA methylation status during cadmium-induced cellular transformation. Exp Cell Res 286: 355-365, 2003.

132. Satarug S, Baker JR, Reilly PE, Moore MR and Williams DJ: Changes in zinc and copper homeostasis in human livers and kidneys associated with exposure to environmental cadmium. Hum Exp Toxicol 20: 205-213, 2001.

133. Sabolić I, Breljak D, Skarica M and Herak-Kramberger CM: Role of metallothionein in cadmium traffic and toxicity in kidneys and other mammalian organs. Biometals 23: 897-926, 2010.

134. Naugler WE, Sakurai T, Kim S, Maeda S, Kim K, Elsharkawy AM and Karin M: Gender disparity in liver cancer due to sex differences in MyD88-dependent IL-6 production. Science 317: 121-124, 2007.

135. International Agency for Research on Cancer (IARC): Chemical Agents and Related Occupations. IARC Monogr Vol 100F. Lyon, France, 2012.

136. International Agency for Research on Cancer (IARC) 1,3-butadiene, ethylene oxide and vinyl halides (vinyl fluoride, vinyl chloride and vinyl bromide). IARC Monogr Vol 97. Lyon, France, 2008.

137. Uccello M, Malaguarnera G, Corriere T, Biondi A, Basile F and Malaguarnera M: Risk of hepatocellular carcinoma in workers exposed to chemicals. Hepat Mon 12: e5943, 2012.

138. Kauppinen T, Toikkanen J, Pedersen D, Young R, Ahrens W, Boffetta P, Hansen J, Kromhout H, Maqueda Blasco J, Mirabelli D, et al: Occupational exposure to carcinogens in the European Union. Occup Environ Med 57: 10-18, 2000.

139. Dobecki M and Romanowicz B: Occupational exposure to toxic substances during the production of vinyl chloride and chlorinated organic solvents. Med Pr 44: 99-102, 1993.

140. Fred C, Törnqvist M and Granath F: Evaluation of cancer tests of 1,3-butadiene using internal dose, genotoxic potency, and a multiplicative risk model. Cancer Res 68: 8014-8021, 2008.

141. Bolt HM: Vinyl chloride-a classical industrial toxicant of new interest. Crit Rev Toxicol 35: 307-323, 2005.

142. Dogliotti E: Molecular mechanisms of carcinogenesis by vinyl chloride. Ann Ist Super Sanita 42: 163-169, 2006. 
143. Boffetta P, Matisane L, Mundt KA and Dell LD: Meta-analysis of studies of occupational exposure to vinyl chloride in relation to cancer mortality. Scand J Work Environ Health 29: 220-229, 2003.

144.Fedeli U and Mastrangelo G: Vinyl chloride industry in the courtroom and corporate influences on the scientific literature. Am J Ind Med 54: 470-473, 2011.

145. Mastrangelo G, Fedeli U, Fadda E, Milan G, Turato A and Pavanello S: Lung cancer risk in workers exposed to poly(vinyl chloride) dust: A nested case-referent study. Occup Environ Med 60: 423-428, 2003

146. Hsieh HI, Chen PC, Wong RH, Du CL, Chang YY, Wang JD and Cheng TJ: Mortality from liver cancer and leukaemia among polyvinyl chloride workers in Taiwan: An updated study. Occup Environ Med 68: 120-125, 2011.

147. Hsieh HI, Wang JD, Chen PC and Cheng TJ: Synergistic effect of hepatitis virus infection and occupational exposures to vinyl chloride monomer and ethylene dichloride on serum aminotransferase activity. Occup Environ Med 60: 774-778, 2003.

148. Marion MJ, Froment O and Trépo C: Activation of Ki-ras gene by point mutation in human liver angiosarcoma associated with vinyl chloride exposure. Mol Carcinog 4: 450-454, 1991.

149. De Vivo I, Marion MJ, Smith SJ, Carney WP and Brandt-Rauf PW: Mutant c-Ki-ras p21 protein in chemical carcinogenesis in humans exposed to vinyl chloride. Cancer Causes Control 5: 273-278, 1994.

150. Hollstein M, Marion MJ, Lehman T, Welsh J, Harris CC, Martel-Planche G, Kusters I and Montesano R: P53 mutations at A: T base pairs in angiosarcomas of vinyl chloride-exposed factory workers. Carcinogenesis 15: 1-3, 1994

151. Maltoni C, Lefemine G, Ciliberti A, Cotti G and Carretti D: Carcinogenicity bioassays of vinyl chloride monomer: A model of risk assessment on an experimental basis. Environ Health Perspect 41: 3-29, 1981.

152. Lee CC, Bhandari JC, Winston JM, House WB, Dixon RL and Woods JS: Carcinogenicity of vinyl chloride and vinylidene chloride. J Toxicol Environ Health 4: 15-30, 1978.

153. Drew RT, Boorman GA, Haseman JK, McConnell EE, Busey WM and Moore JA: The effect of age and exposure duration on cancer induction by a known carcinogen in rats, mice, and hamsters. Toxicol Appl Pharmacol 68: 120-130, 1983.

154.Feron VJ and Kroes R: One-year time-sequence inhalation toxicity study of vinyl chloride in rats. II. Morphological changes in the respiratory tract, ceruminous gland, brain, kidneys, heart and spleen. Toxicology 13: 131-141, 1979.

155. Groth DH, Coate WB, Ulland BM and Hornung RW: Effects of aging on the induction of angiosarcoma. Environ Health Perspect 41: 53-57, 1981.

156. Feron VJ, Hendriksen CF, Speek AJ, Til HP and Spit BJ Lifespan oral toxicity study of vinyl chloride in rats. Food CosmetToxicol 19: 317-333, 1981.

157. Maroni M, Mocci F, Visentin S, Preti G and Fanetti AC: Periportal fibrosis and other liver ultrasonography findings in vinyl chloride workers. Occup Environ Med 60: 60-65, 2003.

158. Maltoni C and Cotti G: Carcinogenicity of vinyl chloride in Sprague-Dawley rats after prenatal and postnatal exposure. Ann NY Acad Sci 534: 145-159, 1988.

159. Til HP, Feron VJ and Immel HR: Lifetime (149-week) oral carcinogenicity study of vinyl chloride in rats. Food Chem Toxicol 29: 713-718, 1991.

160.Feron VJ, Kruysse A and Til HP: One-year time sequence inhalation toxicity study of vinyl chloride in rats. I. Growth, mortality, haematology, clinical chemistry and organ weights. Toxicology 13: 25-28, 1979.

161. Feron VJ, Spit BJ, Immel HR and Kroes R: One-year time-sequence inhalation toxicity study of vinyl chloride in rats. III. Morpho-logical changes in the liver. Toxicology 13: 143-154, 1979

162. World Health Organization (WHO): Nordic Council of Ministers. Organic solvents and the central nervous system, EH5. WHO and Nordic Council of Ministers, Copenhagen, Denmark, pp1-39, 1985.

163. Parrish CF: Solvents, industrial. In: Kirk-Othmer Encyclopedia of chemical technology. Grayson M, Eckroth D, Mark HF Othmer DF, Overberger CG, Seaborg GT (eds). Vol 21. John Wiley \& Sons, Inc., New York, NY, pp377-401, 1983.

164. Bebarta V and DeWitt C: Miscellaneous hydrocarbon solvents. Clin Occup Environ Med 4: 455-479,vi, 2004.

165. Malaguarnera G, Cataudella E, Giordano M, Nunnari G, Chisari G and Malaguarnera M: Toxichepatitis in occupational exposure to solvents. World J Gastroenterol 18: 2756-2766, 2012.
166. Chen R and Seaton A: A meta-analysis of painting exposure and cancer mortality. Cancer Detect Prev 22: 533-539, 1998.

167. International Agency for Research on Cancer (IARC): Dry cleaning, some chlorinated solvents and other industrial chemicals. IARC Monogr Vol 63. Lyon, France, 1995.

168. Alexander DD, Kelsh MA, Mink PJ, Mandel JH, Basu R and Weingart M: A meta-analysis of occupational trichloroethylene exposure and liver cancer. Int Arch Occup Environ Health 81: 127-143, 2007.

169. Caldwell JC and Keshava N: Key issues in the modes of action and effects of trichloroethylene metabolites for liver and kidney tumorigenesis. Environ Health Perspect 114: 1457-1463, 2006.

170. Bradford BU, Lock EF, Kosyk O, Kim S, Uehara T, Harbourt D, DeSimone M, Threadgill DW, Tryndyak V, Pogribny IP, et al: Interstrain differences in the liver effects of trichloroethylene in a multistrain panel of inbred mice. Toxicol Sci 120: 206-217, 2011.

171. National Toxicology Program (NTP): Carcinogenesis studies of trichloroethylene (without epichlorohydrin) (CASs no. 79-01-6) in F344/N rats and B6C3F1 mice (gavage studies). US Department of Health and Human Services, Public Health Service, National Institutes of Health, Research Triangle Park, NC, 1990.

172. International Agency for Research on Cancer (IARC): Trichloroethylene, Tetrachloroethylene and Some Other Chlorinated Agents. IARC Monogr Vol 106. Lyon, France, 2014.

173. Guha N, Loomis D, Grosse Y, Lauby-Secretan B, El Ghissassi F, Bouvard V, Benbrahim-Tallaa L, Baan R, Mattock H and Straif K; International Agency for Research on Cancer Monograph Working Group: Carcinogenicity of trichloroethylene, tetrachloroethylene, some other chlorinated solvents, and their metabolites. Lancet Oncol 13: 1192-1193, 2012.

174. Hansen J, Sallmén M, Seldén AI, Anttila A, Pukkala E, Andersson K, Bryngelsson IL, Raaschou-Nielsen O, Olsen JH and McLaughlin JK: Risk of cancer among workers exposed to trichloroethylene: Analysis of three Nordic cohort studies. J Natl Cancer Inst 105: 869-877, 2013.

175. Rusyn I, Chiu WA, Lash LH, Kromhout H, Hansen J and Guyton KZ: Trichloroethylene: Mechanistic, epidemiologic and other supporting evidence of carcinogenic hazard. Pharmacol Ther 141: 55-68, 2014.

176. Klaunig JE, Babich MA, Baetcke KP, Cook JC, Corton JC, David RM, DeLuca JG, Lai DY, McKee RH, Peters JM, et al: PPARalpha agonist-induced rodent tumors: Modes of action and human relevance. Crit Rev Toxicol 33: 655-780, 2003.

177. Environmental Protection Agency (EPA): Trichloroethylene toxicological review and appendices. Office of Pesticide Programs and Toxic Substances, Washington, D.C., 2011. http://www.epa.gov/iris/supdocs/0199index.html. Accessed January 12, 2016.

178. Laughter AR, Dunn CS, Swanson CL, Howroyd P, Cattley RC and Corton JC: Role of the peroxisome proliferator-activated receptor alpha (PPARalpha) in responses to trichloroethylene and metabolites, trichloroacetate and dichloroacetate in mouse liver. Toxicology 203: 83-98, 2004.

179. Ramdhan DH, Kamijima M, Wang D, Ito Y, Naito H, Yanagiba Y, Hayashi Y, Tanaka N, Aoyama T, Gonzalez FJ and Nakajima T: Differential response to trichloroethylene-induced hepatosteatosis in wild-type and PPARalpha-humanized mice. Environ Health Perspect 118: 1557-1563, 2010.

180.Dunlop MH, Dray E, Zhao W, San Filippo J, Tsai MS, Leung SG, Schild D, Wiese C and Sung P: Mechanistic insights into RAD51-associated protein 1 (RAD51AP1) action in homologous DNA repair. J Biol Chem 287: 12343-12347, 2012.

181.Pogribny IP and Rusyn I: Role of epigenetic aberrations in the development and progression of human hepatocellular carcinoma. Cancer Lett 342: 223-230, 2014.

182. Tao L, Ge R, Xie M, Kramer PM and Pereira MA: Effect of trichloroethylene on DNA methylation and expression of early-intermediate protooncogenes in the liver of $\mathrm{B} 6 \mathrm{C} 3 \mathrm{~F} 1$ mice. J Biochem Mol Toxicol 13: 231-237, 1999.

183. Taira N, Mimoto R, Kurata M, Yamaguchi T, Kitagawa M, Miki Y and Yoshida K: DYRK2 priming phosphorylation of c-Jun and c-Myc modulates cell cycle progression in human cancer cells. J Clin Invest 122: 859-872, 2012.

184. Plo I, Laulier C, Gauthier L, Lebrun F, Calvo F and Lopez BS: AKT1 inhibits homologous recombination by inducing cytoplasmic retention of BRCA1 and RAD51. Cancer Res 68: 9404-9412, 2008. 
185.Gold LS, De Roos AJ, Waters M and Stewart P: Systematic literature review of uses and levels of occupational exposure to tetrachloroethylene. J Occup Environ Hyg 5: 807-839, 2008.

186. Mundt KA, Birk T and Burch MT: Critical review of the epidemiological literature on occupational exposure to perchloroethylene and cancer. Int Arch Occup Environ Health 76: 473-491, 2003.

187. National Toxicology Program: NTP Toxicology and Carcinogenesis Studies of Tetrachloroethylene (Perchloroethylene) (CAS No. 127-18-4) in F344/N Rats and B6C3F1 Mice (Inhalation Studies). Natl Toxicol Program Tech Rep Ser 311: 1-197, 1986.

188. Stemhagen A, Slade J, Altman R and Bill J: Occupational risk factors and liver cancer. A retrospective case-control study of primary liver cancer in New Jersey. Am J Epidemiol 117: 443-454, 1983.

189. Agency for Toxic Substances and Disease Registry (ATSDR): Toxicological profile for tetrachloroethylene (update). US Public Health Service, US Department of Health and Human Services, Atlanta, GA. 1997.

190. Gaikwad AS, Karunamoorthy P, Kondhalkar SJ, Ambikapathy M and Beerappa R: Assessment of hematological, biochemical effects and genotoxicity among pesticide sprayers in grape garden. J Occup Med Toxicol 10: 11, 2015.

191.International Agency for Research on Cancer (IARC): Some thyrotropic agents. IARC Monogr Vol 79. Lyon, France, 2001.

192. Osimitz TG and Lake BG: Mode-of-action analysis for induction of rat liver tumors by pyrethrins: Relevance to human cancer risk. Crit Rev Toxicol 39: 501-511, 2009.

193.Persson EC, Graubard BI, Evans AA, London WT, Weber JP, LeBlanc A, Chen G, Lin W and McGlynn KA: Dichlorodiphenyltrichloroethane and risk of hepatocellular carcinoma. Int J Cancer 131: 2078-2084, 2012.

194. National Toxicology Program: Bioassays of DDT, TDE, and p,p'-DDE for possible carcinogenicity. Natl Cancer Inst Carcinog Tech Rep Ser 131: 1-251, 1978.

195. International Agency for Research on Cancer (IARC): Occupational exposures in insecticide application and some pesticides. IARC Monogr Vol 53. Lyon, France, 1991.

196. National Toxicology Program (NTP): Report on carcinogens. 12th edition. US Department of Health and Human Services, Public Health Service, National Toxicology Program, Research Triangle Park, NC, 2011.

197. Agency for Toxic Substances and Disease Registry (ATSDR): Toxicological profile for DDT, DDE and DDD. US Public Health Service, US Department of Health and Human Services, Atlanta, GA, 2002.

198. World Health Organization (WHO): The use of DDT in malaria vector control: WHO position statement. Geneva, Switzerland, 2007.

199. Rossi L, Barbieri O, Sanguineti M, Cabral JR, Bruzzi P and Santi L: Carcinogenicity study with technical-grade dichlorodiphenyltrichloroethane and 1,1-dichloro-2,2-bis (p-chlorophenyl) ethylene in hamsters. Cancer Res 43: 776-781, 1983.

200.Lipsky MM, Trump BF and Hinton DE: Histogenesis of dieldrin and DDT-induced hepatocellular carcinoma in Balb/c mice. J Environ Pathol Toxicol Oncol 9: 79-93, 1989.

201. Cocco P, Fadda D, Billai B, D'Atri M, Melis M and Blair A: Cancer mortality among men occupationally exposed to dichlorodiphenyltrichloroethane. Cancer Res 65: 9588-9594, 2005.

202. Laws ER Jr, Maddrey WC, Curley A and Burse VW: Long-term occupational exposure to DDT. Arch Environ Health 27: 318-321, 1973

203. Chaturvedi NK, Kumar S, Negi S and Tyagi RK: Endocrine disruptors provoke differential modulatory responses on androgen receptor and pregnane and xenobiotic receptor: Potential implications in metabolic disorders. Mol Cell Biochem 345: 291-308, 2010.

204. Daniel V, Huber W, Bauer K, Suesal C, Conradt C and Opelz G: Associations of dichlorodiphenyltrichloroethane (DDT) 4.4 and dichlorodiphenyldichloroethylene (DDE) 4.4 blood levels with plasma IL-4. Arch Environ Health 57: 541-547, 2002.

205.Angsubhakorn S, Pradermwong A, Phanwichien K and Nguansangiam S: Promotion of aflatoxin B1-induced hepatocarcinogenesis by dichlorodiphenyl trichloroethane (DDT). Southeast Asian J Trop Med Public Health 33: 613-623, 2002.

206. National Toxicology Program: N-Nitrosamines (15 listings): N-Methyl-N'-Nitro-N-Nitrosoguanidine. Rep Carcinog 12: 302-303, 2011.
207. Tolba R, Kraus T, Liedtke C, Schwarz M and Weiskirchen R: Diethylnitrosamine (DEN)-induced carcinogenic liver injury in mice. Lab Anim 49 (Suppl 1): S59-S69, 2015.

208. International Agency for Research on Cancer (IARC): Some inorganic substances, chlorinated hydrocarbons, aromatic amines, N-Nitroso compounds and natural products. IARC Monogr Vol 1. Lyon, France, 1972.

209. Lijinsky W: N-Nitroso compounds in the diet. Mutat Res 443: $129-138,1999$.

210. Gentry PR, House-Knight T, Harris A, Greene T and Campleman S: Potential occupational risk of amines in carbon capture for power generation. Int Arch Occup Environ Health 87: 591-606, 2014

211. Andreotti G and Silverman DT: Occupational risk factors and pancreatic cancer: A review of recent findings. Mol Carcinog 51: 98-108, 2012.

212. Brown JL: N-Nitrosamines. Occup Med 14: 839-848, 1999.

213. Roth VS: Rubber industry epidemiology. Occup Med 14: 849-856, 1999

214. Agency for Toxic Substances and Disease Registry (ATSDR): Toxicological profile for N-Nitrosodimethylamine (final report). US Public Health Service, US Department of Health and Human Services, Atlanta, GA, 1989.

215. Li H, Jönsson BA, Lindh $\mathrm{CH}$, Albin $\mathrm{M}$ and Broberg $\mathrm{K}$ : N-nitrosamines are associated with shorter telomere length. Scand J Work Environ Health 37: 316-324, 2011.

216. Zhang X, Lin S, Funk WE and Hou L: Environmental and occupational exposure to chemicals and telomere length in human studies. Occup Environ Med 70: 743-749, 2013.

217. Morales L, Dachs J, González-Gaya B, Hernán G, Abalos M and Abad E: Background concentrations of polychlorinated dibenzo-p-dioxins, dibenzofurans, and biphenylsin the global oceanic atmosphere. Environ Sci Technol 48: 10198-10207, 2014.

218. International Agency for Research on Cancer (IARC): Polychlorinated dibenzo-para-dioxins and polychlorinated dibenzofurans. IARC Monogr Vol 69. Lyon, France, 1997.

219. Ovando BJ, Ellison CA, Vezina CM and Olson JR: Toxicogenomic analysis of exposure to TCDD, PCB126 and PCB153: Identification of genomic biomarkers of exposure to AhR ligands. BMC Genomics 11: 583, 2010.

220. National Toxicology Program: Toxicology and carcinogenesis studies of 2,3,7,8-tetrachlorodibenzo-p-dioxin (TCDD) (Cas No. 1746-01-6) 2,3,4,7,8-pentachlorodibenzofuran (PeCDF) (Cas No 57117-31-4), and 3,3',4,4',5-pentachlorobiphenyl (PCB 126) (Cas No. 57465-28-8) in female Harlan Sprague-Dawley rats (gavage studies). Natl Toxicol Program Tech Rep Ser 1-180, 2006.

221. Environmental Protection Agency (EPA): Exposure and human health reassessment of 2,3,7,8-tetrachlorodiobenzo-p-dioxin (TCDD) and related compounds. Part I: Estimating exposure to dioxin-like compounds. Vol 2. National Center for Environmental Assessment, Office of Research and Development, Washington, D.C., 2000.

222. Rivera-Austrui J, Martinez K, Marco-Almagro L, Abalos M and Abad E: Long-term sampling of dioxin-like substances from a clinker kiln stack using alternative fuels. Sci Total Environ 485-486: 528-533, 2014.

223. Kociba RJ, Keyes DG, Beyer JE, Carreon RM, Wade CE, Dittenber DA, Kalnins RP, Frauson LE, Park CN, Barnard SD, et al: Results of a two-year chronic toxicity and oncogenicity study of 2,3,7,8-tetrachlorodibenzo-p-dioxin in rats. Toxicol Appl Pharmacol 46: 279-303, 1978.

224. Vezina CM, Walker NJ and Olson JR: Subchronic exposure to TCDD, PeCDF, PCB126, and PCB153: Effect on hepatic gene expression. Environ Health Perspect 112: 1636-1644, 2004

225. Kulkarni PS, Crespo JG and Afonso CA: Dioxins sources and current remediation technologies-a review. Environ Int 34: $139-153,2008$

226. National Toxicology Program: NTP toxicology and carcinogenesis studies of 3,3',4,4',5-pentachlorobiphenyl (PCB 126) (CAS No. 57465-28-8) in female Harlan Sprague-Dawley rats (Gavage Studies). Natl Toxicol Program Tech Rep Ser 4-246, 2006.

227. National Toxicology Program: Toxicology and carcinogenesis studies of 2,3,4,7,8-pentachlorodibenzofuran (PeCDF) (Cas No. 57117-31-4) in female Harlan Sprague-Dawley rats (gavage studies). Natl Toxicol Program Tech Rep Ser 1-198, 2006.

228. Waern F, Flodström S, Busk L, Kronevi T, Nordgren I and Ahlborg UG: Relative liver tumour promoting activity and toxicity of some polychlorinated dibenzo-p-dioxin and dibenzofuran-congeners in female Sprague-Dawley rats. Pharmacol Toxicol 69: 450-458, 1991. 
229. Nishizumi M and Masuda Y: Enhancing effect of 2,3,4,7,8-pentachlorodibenzofuran and 1,2,3,4,7,8-hexachlorodibenzofuran on diethylnitrosamine hepatocarcinogenesis in rats. Cancer Lett 33: 333-339, 1986.

230. Collins JJ, Bodner K, Haidar S, Wilken M, Burns CJ, Lamparski LL, Budinsky RA, Martin GD and Carson ML: Chlorinated dibenzo-p-dioxins, dibenzofurans, and biphenyl profiles of workers with trichlorophenol and pentachlorophenol exposures. Chemosphere 73 (Suppl 1): S284-S289, 2008.

231. Collins JJ, Bodner KM, Wilken M, Haidar S, Burns CJ, Budinsky RA, Martin GD, Carson ML and Rowlands JC: Serum concentrations of chlorinated dibenzo-p-dioxins and dibenzofurans among former Michigan trichlorophenol and pentachlorophenol workers. J Expo Sci Environ Epidemiol 17: 541-548, 2007.

232. Collins JJ, Budinsky RA, Burns CJ, Lamparski LL, Carson ML, Martin GD and Wilken M: Serum dioxin levels in former chlorophenol workers. J Expo Sci Environ Epidemiol 16: 76-84, 2006.

233. Aylward LL, Bodner KM, Collins JJ, Wilken M, McBride D, Burns CJ, Hays SM and Humphry N: TCDD exposure estimation for workers at a New Zealand 2,4,5-T manufacturing facility based on serum sampling data. J Expo Sci Environ Epidemiol 20: 417-426, 2010.

234. Gu YZ, Hogenesch JB and Bradfield CA: The PAS superfamily: Sensors of environmental and developmental signals. Annu Rev Pharmacol Toxicol 40: 519-561, 2000.

235.Petrulis JR and Perdew GH: The role of chaperone proteins in the aryl hydrocarbon receptor core complex. Chem Biol Interact 141: 25-40, 2002.

236. Ramadoss $\mathrm{P}$ and Perdew GH: The transactivation domain of the Ah receptor is a key determinant of cellular localization and ligand-independent nucleocytoplasmic shuttling properties. Biochemistry 44: 11148-11159, 2005.

237. Swanson HI: DNA binding and protein interactions of the AHR/ARNT heterodimer that facilitate gene activation. Chem Biol Interact 141: 63-76, 2002

238. Xu C, Li CY and Kong AN: Induction of phase I, II and III drug metabolism/transport by xenobiotics. Arch Pharm Res 28: 249-268, 2005

239.Kung T, Murphy KA and White LA: The aryl hydrocarbon receptor $(\mathrm{AhR})$ pathway as a regulatory pathway for cell adhesion and matrix metabolism. Biochem Pharmacol 77: 536-546, 2009.

240. Wolff MS: Occupational exposure to polychlorinated biphenyls (PCBs). Environ Health Perspect 60: 133-138, 1985.

241.Zani C, Toninelli G, Filisetti B and Donato F: Polychlorinated biphenyls and cancer: An epidemiological assessment. J Environ Sci Health C Environ Carcinog Ecotoxicol Rev 31: 99-144, 2013.

242. Agency for Toxic Substances and Disease Registry (ATSDR): Toxicological profile for polychlorinated biphenyls (PCBs). US Public Health Service, US Department of Health and Human Services, Atlanta, GA, 2000.

243. Erickson MD and Kaley RG II: Applications of polychlorinated biphenyls. Environ Sci Pollut Res Int 18: 135-151, 2011.

244. Wolff MS and Schecter A: Use of PCB blood levels to assess potential exposure following an electrical transformer explosion. J Occup Med 34: 1079-1083, 1992.

245. Schecter A, Stanley J, Boggess K, Masuda Y, Mes J, Wolff M, Fürst P, Fürst C, Wilson-Yang K and Chisholm B: Polychlorinated biphenyl levels in the tissues of exposed and nonexposed humans. Environ Health Perspect 102 (Suppl 1): S149-S158, 1994.

246. National Toxicology Program: NTP Technical report on the toxicology and carcinogenesis studies of 2,2',4,4',5,5'-hexachlorobiphenyl (PCB 153) (CAS No. 35065-27-1) in female Harlan Sprague-Dawley rats (Gavage studies). Natl Toxicol Program Tech Rep Ser 529: 4-168, 2006.

247. Hennig B, Reiterer G, Toborek M, Matveev SV, Daugherty A, Smart E and Robertson LW: Dietary fat interacts with PCBs to induce changes in lipid metabolism in mice deficient in low-density lipoprotein receptor. Environ Health Perspect 113: 83-87, 2005

248. Glauert HP, Robertson LW and Silberhorn EM: PCBs: Recent advances in environmental toxicology and health effects. In: Robertson LW, Hansen LG, editors. Lexington (KY): University Press of Kentucky; 2001.

249. Norback DH and Weltman RH: Polychlorinated biphenyl induction of hepatocellular carcinoma in the Sprague-Dawley rat. Environ Health Perspect 60: 97-105, 1985.
250. Rayne $\mathrm{S}$ and Forest K: pK(a) values of the monohydroxylated polychlorinated biphenyls (OH-PCBs), polybrominated biphenyls (OH-PBBs), polychlorinated diphenyl ethers (OH-PCDEs), and polybrominated diphenyl ethers (OH-PBDEs). J Environ Sci Health A Tox Hazard Subst Environ Eng 45: 1322-1346, 2010.

251. Ariyoshi N, Yoshimura $\mathrm{H}$ and Oguri K: Identification of in vitro metabolites of $2,4,6,2^{\prime}, 4^{\prime}, 6^{\prime}$-hexachlorobiphenyl from phenobarbital-treated dog liver microsomes. Biol Pharm Bull 16: $852-857,1993$

252. Forgue ST and Allen JR: Identification of an arene oxide metabolite of 2,2',5-5'-tetrachlorobiphenyl by gas chromatography-mass spectroscopy. Chem Biol Interact 40: 233-245, 1982.

253. Kaminsky LS, Kennedy MW, Adams SM and Guengerich FP: Metabolism of dichlorobiphenyls by highly purified isozymes of rat liver cytochrome P-450. Biochemistry 20: 7379-7384, 1981.

254. Stadnicki SS, Lin FS and Allen JR: DNA single strand breaks caused by 2,2',5,5'-tetrachlorobiphenyl and its metabolites. Res Commun Chem Pathol Pharmacol 24: 313-327, 1979.

255. Tampal N, Lehmler HJ, Espandiari P, Malmberg $\mathrm{T}$ and Robertson LW: Glucuronidation of hydroxylated polychlorinated biphenyls (PCBs). Chem Res Toxicol 15: 1259-1266, 2002.

256. Amaro AR, Oakley GG, Bauer U, Spielmann HP and Robertson LW: Metabolic activation of PCBs to quinones: Reactivity toward nitrogen and sulfur nucleophiles and influence of superoxide dismutase. Chem Res Toxicol 9: 623-629, 1996.

257. Oakley GG, Devanaboyina U, Robertson LW and Gupta RC: Oxidative DNA damage induced by activation of polychlorinated biphenyls (PCBs): Implications for PCB-induced oxidative stress in breast cancer. Chem Res Toxicol 9: 1285-1292, 1996.

258. Klaunig JE, Wang Z, Pu X and Zhou S: Oxidative stress and oxidative damage in chemical carcinogenesis. Toxicol Appl Pharmacol 254: 86-99, 2011.

259. Parkinson A, Safe SH, Robertson LW, Thomas PE, Ryan DE, Reik LM and Levin W: Immunochemical quantitation of cytochrome P-450 isozymes and epoxide hydrolase in liver microsomes from polychlorinated or polybrominated biphenyl-treated rats. A study of structure-activity relationships. J Biol Chem 258: 5967-5976, 1983.

260. Ho PW, Garner CE, Ho JW, Leung KC, Chu AC, Kwok KH, Kung MH, Burka LT, Ramsden DB and Ho SL: Estrogenic phenol and catechol metabolites of PCBs modulate catechol-O-methyltransferase expression via the estrogen receptor: Potential contribution to cancer risk. Curr Drug Metab 9: 304-309, 2008.

261. Brown JF Jr, Mayes BA, Silkworth JB and Hamilton SB: Polychlorinated biphenyls modulated tumorigenesis in Sprague Dawley rats: Correlation with mixed function oxidase activities and superoxide $\left(\mathrm{O}_{2}{ }^{*}\right)$ formation potentials and implied mode of action. Toxicol Sci 98: 375-394, 2007.

262. Marabini L, Calò R and Fucile S: Genotoxic effects of polychlorinated biphenyls (PCB 153,138,101,118) in a fish cell line (RTG-2). Toxicol In Vitro 25: 1045-1052, 2011.

263. Cotelle S, Masfaraud JF and Férard JF: Assessment of the genotoxicity of contaminated soil with the Allium/Vicia-micronucleus and the Tradescantia-micronucleus assays. Mutat Res 426: 167-171, 1999.

264. Song YF, Wilke BM, Song XY, Gong P, Zhou QX and Yang GF: Polycyclic aromatic hydrocarbons (PAHs), polychlorinated biphenyls (PCBs) and heavy metals (HMs) as well as their genotoxicity in soil after long-term wastewater irrigation. Chemosphere 65: 1859-1868, 2006.

265. Jacobus JA, Flor S, Klingelhutz A, Robertson LW and Ludewig G: 2-(4'-Chlorophenyl)-1,4-Benzoquinone increases the frequency of micronuclei and shortens telomeres. Environ Toxicol Pharmacol 25: 267-272, 2008.

266. Senthilkumar PK, Klingelhutz AJ, Jacobus JA, Lehmler H, Robertson LW and Ludewig G: Airborne polychlorinated biphenyls (PCBs) reduce telomerase activity and shorten telomere length in immortal human skin keratinocytes (HaCat). Toxicol Lett 204: 64-70, 2011.

267. Senthilkumar PK, Robertson LW and Ludewig G: PCB153 reduces telomerase activity and telomere length in immortalized human skin keratinocytes (HaCaT) but not in human foreskin keratinocytes (NFK). Toxicol Appl Pharmacol 259: 115-123, 2012.

268. Sargent L, Dragan YP, Erickson C, Laufer CJ and Pitot HC: Study of the separate and combined effects of the non-planar 2 , $5,2^{\prime}, 5^{\prime}$ - and the planar 3,4,3',4'-tetrachlorobiphenyl in liver and lymphocytes in vivo. Carcinogenesis 12: 793-800, 1991.

269. Sargent L, Roloff B and Meisner L: In vitro chromosome damage due to PCB interactions. Mutat Res 224: 79-88, 1989. 
270.Espandiari P, Glauert HP, Lehmler HJ, Lee EY, Srinivasan C and Robertson LW: Polychlorinated biphenyls as initiators in liver carcinogenesis: Resistant hepatocyte model. Toxicol Appl Pharmacol 186: 55-62, 2003.

271. Bencko V, Rames J, Ondrusova M, Plesko I, Jurickova L and Trnovec T: Human exposure to polyhalogenated hydrocarbons and incidence of selected malignancies-central European experience. Neoplasma 56: 353-357, 2009.

272. Tsai PC, Ko YC, Huang W, Liu HS and Guo YL: Increased liver and lupus mortalities in 24-year follow-up of the Taiwanese people highly exposed to polychlorinated biphenyls and dibenzofurans. Sci Total Environ 374: 216-222, 2007.

273.Zhao G, Wang Z, Zhou H and Zhao Q: Burdens of PBBs, PBDEs, and PCBs in tissues of the cancer patients in the e-waste disassembly sites in Zhejiang, China. Sci Total Environ 407: 4831-4837, 2009.

274. Bertazzi PA, Riboldi L, Pesatori A, Radice L and Zocchetti C: Cancer mortality of capacitor manufacturing workers. Am J Ind Med 11: 165-176, 1987

275. Greenland S, Salvan A, Wegman DH, Hallock MF and Smith TJ: A case-control study of cancer mortality at a transformer-assembly facility. Int Arch Occup Environ Health 66: 49-54, 1994

276. Mallin K, McCann K, D'Aloisio A, Freels S, Piorkowski J, Dimos J and Persky V: Cohort mortality study of capacitor manufacturing workers, 1944-2000. J Occup Environ Med 46 565-576, 2004.

277. Prince MM, Ruder AM, Hein MJ, Waters MA, Whelan EA, Nilsen N, Ward EM, Schnorr TM, Laber PA and Davis-King KE Mortality and exposure response among 14,458 electrical capacitor manufacturing workers exposed to polychlorinated biphenyls (PCBs). Environ Health Perspect 114: 1508-1514, 2006

278. International Agency for Research on Cancer (IARC): Overall Evaluations of Carcinogenicity: An Updating of IARC Monographs Volumes 1-42. IARC Monogr Supplement 7. Lyon, France, 1987.

279.Lauby-Secretan B, Loomis D, Grosse Y, El Ghissassi F, Bouvard V, Benbrahim-Tallaa L, Guha N, Baan R, Mattock H and Straif K; WHO International Agency for Research on Cancer: Carcinogenicity of polychlorinated biphenyls and polybrominated biphenyls. Lancet Oncol 14: 287-288, 2013.

280. International Agency for Research on Cancer (IARC): Polychlorinated biphenyls and polybrominated biphenyls. IARC Monogr Vol 107. Lyon, France, 2014

281. National Toxicology Program (NTP): Toxicology and carcinogenesis studies of a polybrominated biphenyl mixture (firemaster FF-1) (CAS No. 67774-32-7) in F344/N rats and B6C3F1 mice (gavage study). US Department of Health and Human Services, Public Health Service, National Institutes of Health, Research Triangle Park, NC, 1983.

282. Hoque A, Sigurdson AJ, Burau KD, Humphrey HE, Hess KR and Sweeney AM: Cancer among a Michigan cohort exposed to polybrominated biphenyls in 1973. Epidemiology 9: 373-378, 1988.

283. National Toxicology Program: Polybrominated biphenyls. Rep Carcinog 12: 347-349, 2011.

284. Hanari N, Kannan K, Miyake Y, Okazawa T, Kodavanti PR, Aldous KM and Yamashita N: Occurrence of polybrominated biphenyls, polybrominated dibenzo-p-dioxins, and polybrominated dibenzofurans as impurities in commercial polybrominated diphenyl ether mixtures. Environ Sci Technol 40: 4400-4405, 2006.

285. Sjödin A, Carlsson H, Thuresson K, Sjölin S, Bergman A and Ostman C: Flame retardants in indoor air at an electronics recycling plant and at other work environments. Environ Sci Technol 35: 448-454, 2001.

286.Jira R, Kopp E, McKusick BC, Röderer G, Bosch A and Fleischmann G: Chloroacetaldehydes. In: Ullmann's Encyclopedia of Industrial Chemistry, Electronic Release, 7th edition, Wiley-VCH, Weinheim, 2007.

287. Bor̆tsov AN, Rotenberg IuS and Mulenkova VG: Toxicologic assessment of chloral in the process of its liberation during filling and pouring of foam polyurethanes. Gig Tr Prof Zabol 14: 26-29, 1970 (In Russian)

288. Whistler RL and Zysk JR: Carbohydrates. In: Kirk-Othmer Encyclopedia of Chemical Technology. Mark HF, Othmer DP and Overberger EG (eds). 3rd edition. John Wiley \& Sons, Inc., New York, NY, pp535-555, 1978.

289. Ohlson J: Dry etch chemical safety. Solid State Technol 6: 69-73, 1986.
290. International Agency for Research on Cancer (IARC): Some chemicals present in industrial and consumer products, food and drinking-water. IARC Monogr Vol 101. Lyon, France, 2012.

291. Rijhsinghani KS, Abrahams C, Swerdlow MA, Rao KV and Ghose T: Induction of neoplastic lesions in the livers of C57BL $x$ C3HF1 mice by chloral hydrate. Cancer Detect Prev 9: 279-288, 1986.

292. Leakey JE, Seng JE, Latendresse JR, Hussain N, Allen LJ and Allaben WT: Dietary controlled carcinogenicity study of chloral hydrate in male B6C3F1 mice. Toxicol Appl Pharmacol 193: 266-280, 2003.

293. US Department of Health and Human Services, National Toxicology Program: Toxicology and carcinogenesis study of chloral hydrate (ad libitum and dietary controlled) (CAS no. 302-17-0) in male B6C3F1 mice (gavage study). US Department of Health and Human Services, Public Health Service, National Institutes of Health, Research Triangle Park, NC, 2002.

294. National Toxicology Program (NTP): Report on Carcinogens. o-Toluidine. 14th edition. US Department of Health and Human Services, Public Health Service, National Toxicology Program, Research Triangle Park, NC, 2016.

295. International Agency for Research on Cancer (IARC): Some aromatic amines, organic dyes and related exposures. IARC Monogr Vol 99. Lyon, France, 2010.

296. Kauppinen T, Pukkala E, Saalo A and Sasco AJ: Exposure to chemical carcinogens and risk of cancer among Finnish laboratory workers. Am J Ind Med 44: 343-350, 2003.

297. Akyüz M and Ata S: Determination of aromatic amines in hair dye and henna samples by ion-pair extraction and gas chromatography-mass spectrometry. J Pharm Biomed Anal 47: 68-80, 2008

298. Johansson GM, Jönsson BA, Axmon A, Lindh CH, Lind ML, Gustavsson M, Broberg K, Boman A, Meding B, Lidén C and Albin M: Exposure of hairdressers to ortho- and meta-toluidine in hair dyes. Occup Environ Med 72: 57-63, 2015.

299. Sorahan T, Hamilton L and Jackson JR: A further cohort study of workers employed at a factory manufacturing chemicals for the rubber industry, with special reference to the chemicals 2-mercaptobenzothiazole (MBT), aniline, phenyl-beta-naphthylamine and o-toluidine. Occup Environ Med 57: 106-115, 2000.

300. Sorahan T: Bladder cancer risks in workers manufacturing chemicals for the rubber industry. Occup Med (Lond) 58: 496-501, 2008

301. National Toxicology Program: Bioassay of o-toluidine hydrochloride for possible carcinogenicity. Natl Cancer Inst Carcinog Tech Rep Ser 153: 1-147, 1979.

302. National Toxicology Program: NTP 11th report on carcinogens. Rep Carcinog 11: A1-A32, 2005

303. O'Neil MJ: The Merck Index. 14th ed. Merck \& Co. Inc., Whitehouse Station, NJ, 2006.

304. International Agency for Research on Cancer (IARC) Occupational exposures of hairdressers and barbers and personal use of hair colourants; some hair dyes, cosmetic colourants, industrial dyestuffs and aromatic amines. IARC Monogr Vol 57. Lyon, France, 1993.

305. Stula EF, Sherman H, Zapp JA Jr and Clayton JW Jr: Experimental neoplasia in rats from oral administration of 3,3'-dichlorobenzidine, 4,4'-methylene-bis-bis(2-chloroaniline), and 4,4'-meth-ylene-bis (2-methylaniline). Toxicol Appl Pharmacol 31: 159-176, 1975.

306. Kommineni C, Groth DH, Frockt IJ, Voelker RW and Stanovick RP: Determination of the tumorigenic potential of methlene-bis-orthochloroaniline. J Environ Pathol Toxicol 2: 149-171, 1979.

307.Zhang YJ: Interactions of chemical carcinogens and genetic variation in hepatocellular carcinoma. World J Hepatol 2: 94-102, 2010.

308. Collins JJ, Strauss ME, Levinskas GJ and Conner PR: The mortality experience of workers exposed to 2,3,7,8-tetrachlorodibenzo-p-dioxin in a trichlorophenol process accident. Epidemiology 4: 7-13, 1993.

309. Melick WF, Naryka JJ and Kelly RE: Bladder cancer due to exposure to para-aminobiphenyl: A 17-year followup. J Urol 106: 220-226, 1971

310. Schieferstein GJ, Littlefield NA, Gaylor DW, Sheldon WG and Burger GT: Carcinogenesis of 4-aminobiphenyl in BALB/cStCr-lfC3Hf/Netr mice. Eur J Cancer Clin Oncol 21: $865-873,1985$ 
311. Clayson DB, Lawson TA and Pringle JA: The carcinogenic action of 2-aminodiphenylene oxide and 4-aminodiphenyl on the bladder and liver of the C57 X IF mouse. Br J Cancer 21: 755-762, 1967.

312. Deichmann WB, Radomski J, Glass E, Anderson WA, Coplan M and Woods F: Synergism among oral carcinogens. 3. simultaneous feeding of four bladder carcinogens to dogs. Ind Med Surg 34: 640-649, 1965.

313. Block NL, Sigel MM, Lynne CM, Ng AB and Grosberg RA: The initiation, progress, and diagnosis of dog bladder cancer induced by 4-aminobiphenyl. Invest Urol 16: 50-54, 1978.

314. Gorrod JW, Carter RL and Roe FJ: Induction of hepatomas by 4-aminobiphenyl and three of its hydroxylated derivatives administered to newborn mice. J Natl Cancer Inst 41: 403-410, 1968.

315. Dooley KL, Von Tungeln LS, Bucci T, Fu PP and Kadlubar FF: Comparative carcinogenicity of 4-aminobiphenyl and the food pyrolysates, Glu-P-1, IQ, PhIP, and MeIQx in the neonatal B6C3F1 male mouse. Cancer Lett 62: 205-209, 1992.

316. Parsons BL, Beland FA, Von Tungeln LS, Delongchamp RR, Fu PP and Heflich RH: Levels of 4-aminobiphenyl-induced somatic H-ras mutation in mouse liver DNA correlate with potential for liver tumor development. Mol Carcinog 42: 193-201, 2005.

317. Butler MA, Iwasaki M, Guengerich FP and Kadlubar FF: Human cytochrome P-450A (P-4501A2), the phenacetin O-deethylase, is primarily responsible for the hepatic 3-demethylation of caffeine and $\mathrm{N}$-oxidation of carcinogenic arylamines. Proc Nat Acad Sci USA 86: 7696-7700, 1989.

318. Bartsch H, Malaveille C, Friesen M, Kadlubar FF and Vineis P: Black (air-cured) and blond (flue-cured) tobacco cancer risk IV: Molecular dosimetry studies implicate aromatic amines as bladder carcinogens. Eur J Cancer 29A: 1199-1207, 1993.

319. Talaska G, Dooley KL and Kadlubar FF: Detection and characterization of carcinogen-DNA adducts in exfoliated urothelial cells from 4-aminobiphenyl-treated dogs by 32P-postlabelling and subsequent thin-layer and high-pressure liquid chromatography. Carcinogenesis 11: 639-646, 1990

320. Kadlubar FF: DNA adducts of carcinogenic aromatic amines In: DNA adducts identification and biological significance. Hemminki KDASDE (ed). OXford University Press, New York, NY, pp199-215, 1994.

321. Poirier MC, Fullerton NF, Smith BA and Beland FA: DNA adduct formation and tumorigenesis in mice during the chronic administration of 4-aminobiphenyl at multiple dose levels. Carcinogenesis 16: 2917-2921, 1995.

322.Zack JA and Gaffey WR: A mortality study of workers employed at the Monsanto Company plant in Nitro, West Virginia. Environ Sci Res 26: 575-591, 1983.

323. Wang LY, Chen CJ, Zhang YJ, Tsai WY, Lee PH, Feitelson MA, Lee CS and Santella RM: 4-Aminobiphenyl DNA damage in liver tissue of hepatocellular carcinoma patients and controls. Am J Epidemiol 147: 315-323, 1998.

324.Curigliano G, Zhang YJ, Wang LY, Flamini G, Alcini A, Ratto C, Giustacchini M, Alcini E, Cittadini A and Santella RM: Immunohistochemical quantitation of 4-aminobiphenyl-DNA adducts and p53 nuclear overexpression in T1 bladder cancer of smokers and nonsmokers. Carcinogenesis 17: 911-916, 1996.

325. NIOSH: Special occupational hazard review for benzidine-based dyes. NIOSH Criteria Documents. US Department of Health, Education and Welfare, Public Health Services, Center for Disease Control, Atlanta, GA, p60, 1980.

326. Ahlström LH, Sparr Eskilsson C and Björklund E: Determination of banned azo dyes in consumer goods. Trends in Analytical Chemistry 24: 49-56, 2005.

327. International Agency for Research on Cancer (IARC): Some industrial chemicals and dyestuffs. IARC Monogr Vol 29. Lyon, France, 1982.

328. Garrigós MC, Reche F, Marín ML and Jiménez A: Determination of aromatic amines formed from azo colorants in toy products. J Chromatogr A 976: 309-317, 2002.

329. Lancaster FE and Lawrence JF: Determination of benzidine in the food colours tartrazine and sunset yellow FCF, by reduction and derivatization followed by high-performance liquid chromatography. Food Addit Contam 16: 381-390, 1999.

330. Robens JF, Dill GS, Ward JM, Joiner JR, Griesemer RA and Douglas JF: Thirteen-week subchronic toxicity studies of Direct Blue 6, Direct Black 38, and Direct Brown 95 dyes. Toxicol Appl Pharmacol 54: 431-442, 1980.
331. National Toxicology Program: 13-week subchronic toxicity studies of direct blue 6, direct black 38, and direct brown 95 dyes. Natl Cancer Inst Carcinog Tech Rep Ser 108: 1-117, 1978.

332. Williams JH, Phillips TD, Jolly PE, Stiles JK, Jolly CM and Aggarwal D: Human aflatoxicosis in developing countries: A review of toxicology, exposure, potential health consequences, and interventions. Am J Clin Nutr 80: 1106-1122, 2004.

333. Strosnider H, Azziz-Baumgartner E, Banziger M, Bhat RV, Breiman R, Brune MN, DeCock K, Dilley A, Groopman J, Hell K, et al: Workgroup report: Public health strategies for reducing aflatoxin exposure in developing countries. Environ Health Perspect 114: 1898-1903, 2006.

334. London WT and McGlynn KA: Cancer epidemiology and prevention. In: Cancer Epidemiology and Prevention. Schottenfeld D and Fraumeni Jr JF (eds). 3rd edition. Oxford University Press, New York, NY, pp763-786, 2006.

335. Liu Y and Wu F: Global burden of aflatoxin-induced hepatocellular carcinoma: A risk assessment. Environ Health Perspect 118: 818-824, 2010.

336. International Agency for Research on Cancer (IARC): Some naturally occurring substances: Food items and constituents, heterocyclic aromatic amines and mycotoxins. IARC Monogr Vol 56. Lyon, France, 1993.

337. Dash B, Afriyie-Gyawu E, Huebner HJ, Porter W, Wang JS, Jolly PE and Phillips TD: Determinants of the variability of aflatoxin-albumin adduct levels in Ghanaians. J Toxicol Environ Health A 70: 58-66, 2007.

338. Viegas S, Veiga L, Figueiredo P, Almeida A, Carolino E and Viegas C. Assessment of workers' exposure to aflatoxin B1 in a Portuguese waste industry. Ann Occup Hyg 59: 173-181, 2015.

339. Josephy PD: Molecular Toxicology. Oxford University Press, New York, NY, 1997.

340. Autrup JL, Schmidt J, Seremet T and Autrup H: Determination of exposure to aflatoxins among Danish workers in animal-feed production through the analysis of aflatoxin B1 adducts to serum albumin. Scand J Work Environ Health 17: 436-440, 1991.

341. Doi AM, Patterson PE and Gallagher EP: Variability in aflatoxin B(1)-macromolecular binding and relationship to biotransformation enzyme expression in human prenatal and adult liver. Toxicol Appl Pharmacol 181: 48-59, 2002.

342. Diaz GJ, Murcia HW and Cepeda SM: Cytochrome P450 enzymes involved in the metabolism of aflatoxin B1 in chickens and quail. Poult Sci 89: 2461-2469, 2010.

343. Long XD, Ma Y, Zhou YF, Yao JG, Ban FZ, Huang YZ and Huang BC: XPD codon 312 and 751 polymorphisms, and AFB1 exposure, and hepatocellular carcinoma risk. BMC Cancer 9: 400,2009

344. Lai H, Mo X, Yang Y, He K, Xiao J, Liu C, Chen J and Lin Y: Association between aflatoxin $\mathrm{B} 1$ occupational airway exposure and risk of hepatocellular carcinoma: A case-control study. Tumour Biol 35: 9577-9584, 2014.

345. Kirk GD, Camus-Randon AM, Mendy M, Goedert JJ, Merle P, Trépo C, Bréchot C, Hainaut P and Montesano R: Ser-249 p53 mutations in plasma DNA of patients with hepatocellular carcinoma from The Gambia. J Natl Cancer Inst 92: 148-153, 2000.

346. Gouas D, Shi H and Hainaut P: The aflatoxin-induced TP53 mutation at codon 249 (R249S): Biomarker of exposure, early detection and target for therapy. Cancer Lett 286: 29-37, 2009.

347. Traverso A, Bassoli V, Cioè A, Anselmo S andFerro M: Assessment of aflatoxin exposure of laboratory worker during food contamination analyses. Assessment of the procedures adopted by an A.R.P.A.L. laboratory (Liguria Region Environmental Protection Agency). Med Lav 101: 375-380, 2010.

348. Saad-Hussein A, Taha MM, Beshir S, Shahy EM, Shaheen W and Elhamshary M: Carcinogenic effects of aflatoxin B1 among wheat handlers. Int J Occup Environ Health 20: 215-219, 2014.

349. Saad-Hussein A, Beshir S, Moubarz G, Elserougy S and Ibrahim MI: Effect of exposure to aflatoxins on some liver tumor markers in textile workers. Am J Ind Med 56: 818-824, 2013.

350. Rapisarda V, Valentino M, Bolognini S and Fenga C: Noise-related occupational risk aboard fishing vessels: Considerations on prevention and the protection of exposed workers. G Ital Med Lav Ergon 26: 191-196, 2004 (In Italian).

351. Rapisarda V, Ledda C, Castaing M, Proietti L and Ferrante M: Potential exposure to carcinogens in low-melting alloys processing. G Ital Med Lav Ergon 35: 73-76, 2013 (In Italian). 
352. Rapisarda V, Valentino M, Ravalli P, Fenga C and Duscio D: Occupational brucellosis in slaughtering of sheep and goats Study of five cases from a municipal abattoir in south-eastern Sicily. Med Lav 96: 134-141, 2005 (In Italian).

353. Valentino M, Rapisarda V, Scalise L, Paone N, Santarelli L, Fenga C and Rossi GL: A new method for the experimental assessment of finger haemodynamic effects induced by a hydraulic breaker in operative conditions. J Occup Health 46: 253-259, 2004.

354. Rapisarda V, Bracci M, Nunnari G, Ferrante M and Ledda C: Tetanus immunity in construction workers in Italy. Occup Med (Lond) 64: 217-219, 2014.
355. Valentino M and Rapisarda V: Tetanus in a central Italian region: Scope for more effective prevention among unvaccinated agricultural workers. Occup Med (Lond) 51: 114-117, 2001.

356. Rapisarda V, Ledda C, Ferrante M, Fiore M, Cocuzza S, Bracci M and Fenga $C$ : Blood pressure and occupational exposure to noise and lead $(\mathrm{Pb})$ : A cross-sectional study. Toxicol Ind Health pii: $0748233715576616,2015$.

357. Kim HR and Kim TW: Occupational hepatic disorders in Korea. J Korean Med Sci 25 (Suppl): S36-S40, 2010.

358. Montesano R and Hall J: Environmental causes of human cancers. Eur J Cancer 37 (Suppl 8): S67-S87, 2001. 